\title{
Snow-bed communities with dominant Salix herbacea in the Julian Alps
}

\author{
Andrej Martinčič ${ }^{1}$, †Tone Wraber \& Igor Dakskobler ${ }^{2, *}$
}

Key words: phytosociology, plant ecology, synsystematics, Salicetea herbaceae, Salicetum retuso-herbaceae, Polytrichetum sexangularis, Julian Alps, Triglav National Park, Slovenia, Italy.

Ključne besede: fitocenologija, ekologija rastlin, sinsistematika, Salicetea herbaceae, Salicetum retusoherbaceae, Polytrichetum sexangularis, Julijske Alpe, Triglavski narodni park, Slovenija, Italija.

Received: 11.5 .2018

Revision received: 31.8 .2018

Accepted: 5. 9. 2018

\begin{abstract}
In the alpine belt of the Julian Alps (glacial cirque Na Jezerih under Mt. Veliki Rokav, Jarečica, the Mangart Saddle and Prodi under Mt. Mangart as well as Mt. Plešivec in the rock wall of Loška Stena) we studied the phytosociology and ecology of snow-bed vegetation with dominating flowering plants Salix herbacea, Luzula alpinopilosa, Gnaphalium supinum, Soldanella pusilla and Salix retusa, and numerous moss species. Based on the comparison with similar snow-bed communities in the Central, Eastern and Southern Alps we described a new association Salicetum retuso-herbaceae and classified it into the alliance Salicion herbaceae and class Salicetea herbaceae. We determined several successional stages of snow-bed vegetation on mixed calcareous-silicate bedrock that we treat as variants, in two relevés also the initial association Polytrichetum sexangularis.

Izvleček

V alpinskem pasu Julijskih Alp (ledeniška krnica Na jezerih pod Velikim Rokavom, Jarečica, Mangartsko sedlo in Prodi pod Mangartom ter Plešivec v Loški steni) smo fitocenološko in ekološko preučili vegetacijo snežnih dolinic s prevladujočimi cvetnicami Salix herbacea, Luzula alpinopilosa, Gnaphalium supinum, Soldanella pusilla in Salix retusa ter številnimi mahovnimi vrstami. Na podlagi primerjave s podobnimi združbami snežnih tal v Centralnih, Vzhodnih in Južnih Alpah smo opisali novo asociacijo Salicetum retuso-herbaceae, ki jo uvrščamo v zvezo Salicion herbaceae in razred Salicetea herbaceae. Ugotovili smo več različnih razvojnih stopenj rastja na snežnih tleh na mešani karbonatno-silikatni podlagi, ki jih vrednotimo kot variante, le v dveh popisih tudi inicialno asociacijo Polytrichetum sexangularis.
\end{abstract}

1 Zaloška 78 a, SI-1000 Ljubljana, Slovenia. E-mail: andrej.martincic@siol.net

2 Scientific Research Centre of the Slovenian Academy of Sciences and Arts, Institute of Biology, Regional unit Tolmin, Brunov drevored 13, SI-5220 Tolmin, Slovenia. E-mail: Igor.Dakskobler@zrc-sazu.si.

* Corresponding author. 


\section{Introduction}

Alpine-subnival or snow-bed communities in the Slovenian Alps are confined to areas with long-lasting snow cover that receive a continued supply of snow water (the soil is waterlogged due to snowmelt). The most characteristic snow-bed communities (class Salicetea herbaceae) are distributed only on small areas, mostly in stands of the associations Polytrichetum sexangularis (syn. Polytrichetum norvegicae), Salicetum herbaceae s. lat. and Luzuletum alpinopilosae (T. Wraber 1996a: 109-110). More widely distributed is vegetation of snow-beds on stabilised calcareous screes with some other willows like Salix retusa and S. reticulata (alliance Arabidion caeruleae). The dwarf willow community (Salicetum herbaceae s. lat.) or its stands were reported for areas under Mt. Mangart, in the Škrlatica group, on the Kriški Podi plateau and on Mt. Stol in the Karavanke Mts. (Aichinger 1933: 53-54, T. Wraber in Hegi et al. 1982: 31, T. Wraber 1996a: 109110, 1996b: 93). Only one relevé has been published so far for the association Salicetum herbaceae s. lat. (T. Wraber 1972: 61, Šilc \& Čarni 2012: 136). Aichinger (ibid.) published only the species composition of the stand in the corner between both summits of Mt. Stol: Salix herbacea, Sibbaldia procumbens, Gnaphalium supinum, Anthelia juratzkana, Potentilla aurea, Sagina saginoides, Poa alpina and Polytrichum juniperinum. The current distribution of dwarf willow in Slovenia is shown in Figure 1.

A detailed study of the phytosociology and ecology of stands with dominating Salix herbacea in the Julian Alps was conducted by Andrej Martinčič and late Tone Wraber (1938-2010) in early September 1968 in the Škrlatica group, the cirque $\mathrm{Na}$ Jezerih (Na Jezeru) under Visoki Rokav (9549/3) - Figure 7, and two years later, at the beginning of September 1970, under Mangart (on the Mangart Saddle, in the hollow Prodi) - Figure 6 - quadrant 9547/4. During this research, Andrej Martinčič collected and subsequently determined moss species as well as conducted field measurements of ecological variables (in particular $\mathrm{pH}$ ). The field material, however, was not processed and published due to Tone Wraber's disease and untimely death. A few years be-

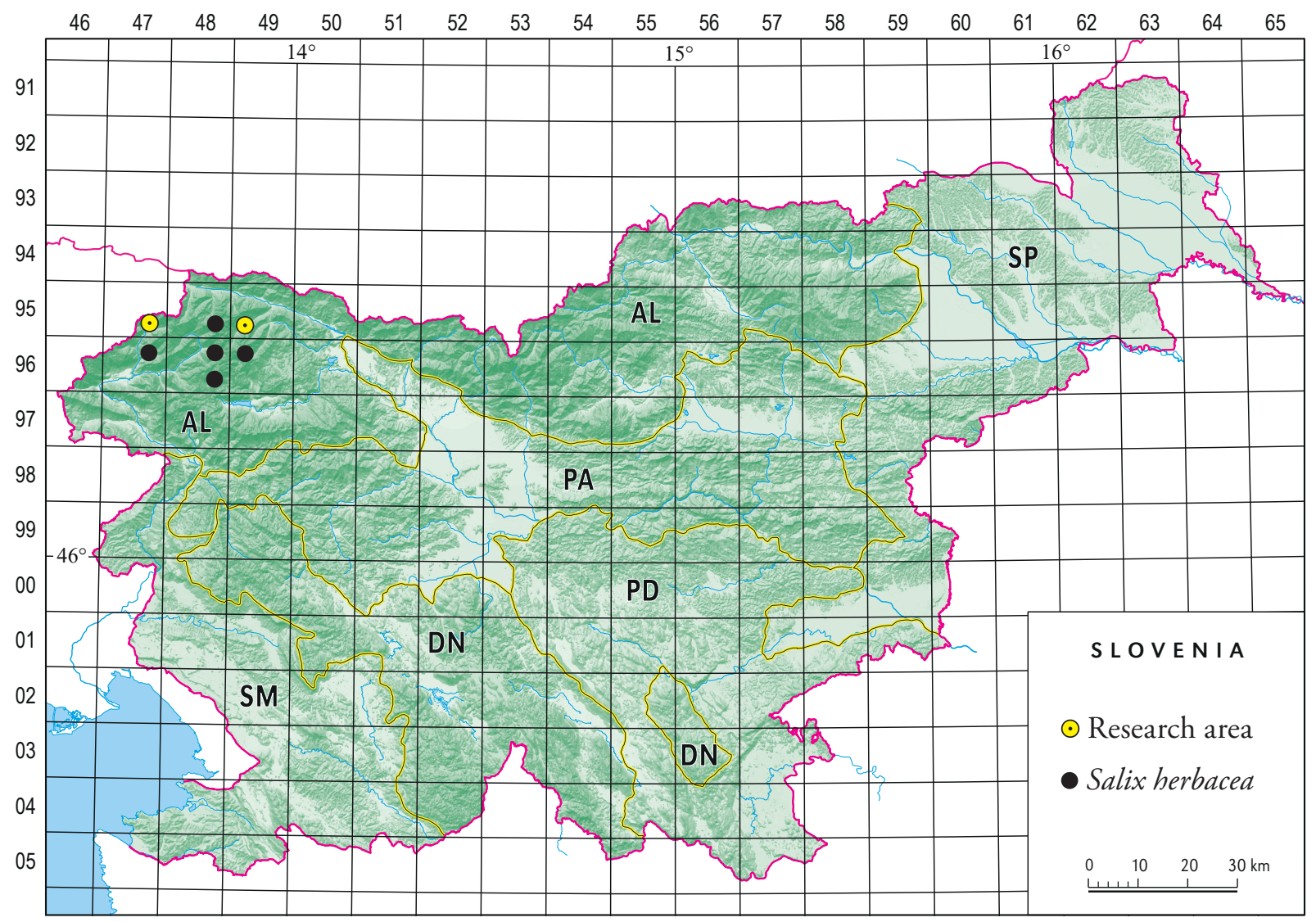

Figure 1: Distribution of Salix herbacea in Slovenia and approximate designation of the research area Slika 1: Razširjenost vrste Salix herbacea v Sloveniji in približna oznaka raziskovalnega območja 
fore he died Wraber had told Igor Dakskobler about his intention to process the field material with Andrej Martinčič. Thanks to Wraber's heirs (widow, son and daughter) and Jože Bavcon, the head of the Botanical Garden of the University of Ljubljana, the professional manuscript legacy of Tone Wraber has been preserved in Wraber's library at the Botanical Garden and is available for researchers to examine. Having studied the phytosociological relevés of other alpine communities in Wraber's field notes on several occasions, we came across the relevés of snow beds as well. Since the co-author of those relevés, Andrej Martinčič, is still a prolific researcher, we wanted to finish what late Tone Wraber had started, i.e. conduct a phytosociological analysis of his relevé material on dwarf willow communities and Igor Dakskobler's relevés from Mt. Mangart and Mt. Plešivec in the Loška Stena rock wall (both in quadrant 9547/4) and classify the determined communities within the applicable syntaxonomic system.

\section{Methods}

Snow-bed communities with dominant Salix herbacea were studied applying the Braun-Blanquet method (Braun-Blanquet 1964). The relevés were entered into the FloVegSi database (Fauna, Flora, Vegetation and Paleovegetation of Slovenia) of the Jovan Hadži Institute of Biology at ZRC SAZU (T. Seliškar et al. 2003). Their arrangement in Table 1 is based on hierarchical classification. We transformed the combined cover-abundance values with numerical values (1-9) according to van der Maarel (1979). Numerical comparisons were performed with the SYN-TAX 2000 program package (Podani 2001). The relevés were compared by means of "(unweighted) average linkage method" - UPGMA, using Wishart's similarity ratio. Communities from Slovenia (some relevés on Mt. Mangart are in the territory of Italy) were compared with similar, already described communities in the Alps. We constructed a synoptic table (Table 2). Hierarchical classification was employed in this comparison as well, and the same method was used as in our comparison of individual relevés, but the measure of dissimilarity was also Jaccard's Index. The first author, Andrej Martinčič, conducted onsite $\mathrm{pH}$ measurements of the soil samples in water solution, using a battery-operated Iskra $\mathrm{pH}$ metre.

The nomenclatural sources for the names of vascular plants are the Mala flora Slovenije (MFS - Martinčič et al. 2007) and Flora alpina (Aeschimann et al. 2004). The nomenclature of Flora alpina - Sesleria caerulea, Gnaphalium supinum was used for the taxa Sesleria caerulea subsp. calcaria and Omalotheca supina (MFS). Ros et al. (2007) is the nomenclatural source for the names of liverworts (Marchanthiophyta), Ros et al. (2013) for the names of mosses and Wirth (1995) and Suppan et al. (2000) for the names of lichens. For the names of syntaxa we follow Englisch (1993, 1999), Grabherr \& Mucina (1993), Theurillat (2004), Šilc \& Čarni (2012) and Mucina et al. (2016). In the classification of vascular species into phytosociological groups (groups of diagnostic species) we mainly refer to the Flora alpina (Aeschimann et al. 2004). Our classification of bryophytes is based on Oberdorfer (1992), English $(1993,1999)$ and the expertise of the first author (Andrej Martinčič). The geographic coordinates of relevés were based on the Slovenian geographic coordinate system D 48 (zone 5) on the Bessel ellipsoid and with Gauss-Krüger projection.

\subsection{Ecological conditions in the studied communities with Salix herbacea}

All the relevés discussed in this article were made in the alpine belt of the Julian Alps, most of them only on five localities: three under Mangart (the Mangart Saddle, Prodi, Jarečica), one on Na Jezerih below Visoki Rokavi, and one on Plešivec in the Loška Stena group, at elevations between 1,950 and $2,220 \mathrm{~m}$. The geological bedrock in the study area is mainly limestone and dolomite limestone interlayered with more silicate rocks, marlstone, claystone and chert, often also fine gravel (Buser 2009). Soils are initial (lithosols, very shallow molic gleysols or even histosols), often with mull humus (Vidic et al. 2015, Vrščaj et al. 2017).

The climate in the study area is montane, with mean annual precipitation of 2,000 to $2,500 \mathrm{~mm}$ (Zupančič 1998) and mean annual air temperature of $-2{ }^{\circ} \mathrm{C}$ to $0{ }^{\circ} \mathrm{C}$ (Cegnar 1998). The researched stands are usually covered with snow from November to June. The growing season usually lasts three to four months, from June to the end of September (or beginning of October). The communities with Salix herbacea are often associated with specific sites, both in terms of terrain, soil conditions and the local climate.

\section{Results and discussion}

\subsection{Soil analysis}

Although the parent material and the soil in individual research plots differ, $\mathrm{pH}$ measurements revealed that the soil in dwarf willow stands is always acidic. Soil $\mathrm{pH}$ values at $\mathrm{Na}$ Jezerih below Rokavi ranged between 4.5 and 5.6; the $\mathrm{pH}$ value in most of the samples was 4.8 to 5.3. In several cases measurements showed an increased $\mathrm{pH}$ value 
(5.6) at the depth of 5-10 cm, and in some cases lower values were determined (with $\mathrm{pH} 4.1$ being the lowest). Soil samples from the Mangart Saddle had $\mathrm{pH}$ values ranging from 4.7 to 5.3 ; the most frequent $\mathrm{pH}$ values were around 5 .

\subsection{Description of the investigated communities}

\subsubsection{Hierarchical classification of relevés}

In hierarchical classification, 46 snow-bed stands in the Julian Alps that are usually dominated by Salix herbacea grouped as demonstrated in Figure 2. In Table 1 they are arranged in the same order, with the exception of several relevés in the right part of the dendrogram.

\subsubsection{Comparison of Salix herbacea communities in the Julian Alps with similar communities in the Alps}

In the next step we made a synoptic table (Table 2) comprising 23 relevés from Table 1, which grouped on the left side of the dendrogram in Figure 2 (the stands marked as Srhty and Srhla), and different forms of communities with dominant Salix herbacea in the Central and Eastern Alps, and compared them through hierarchical classification (Figures 3 and 4).

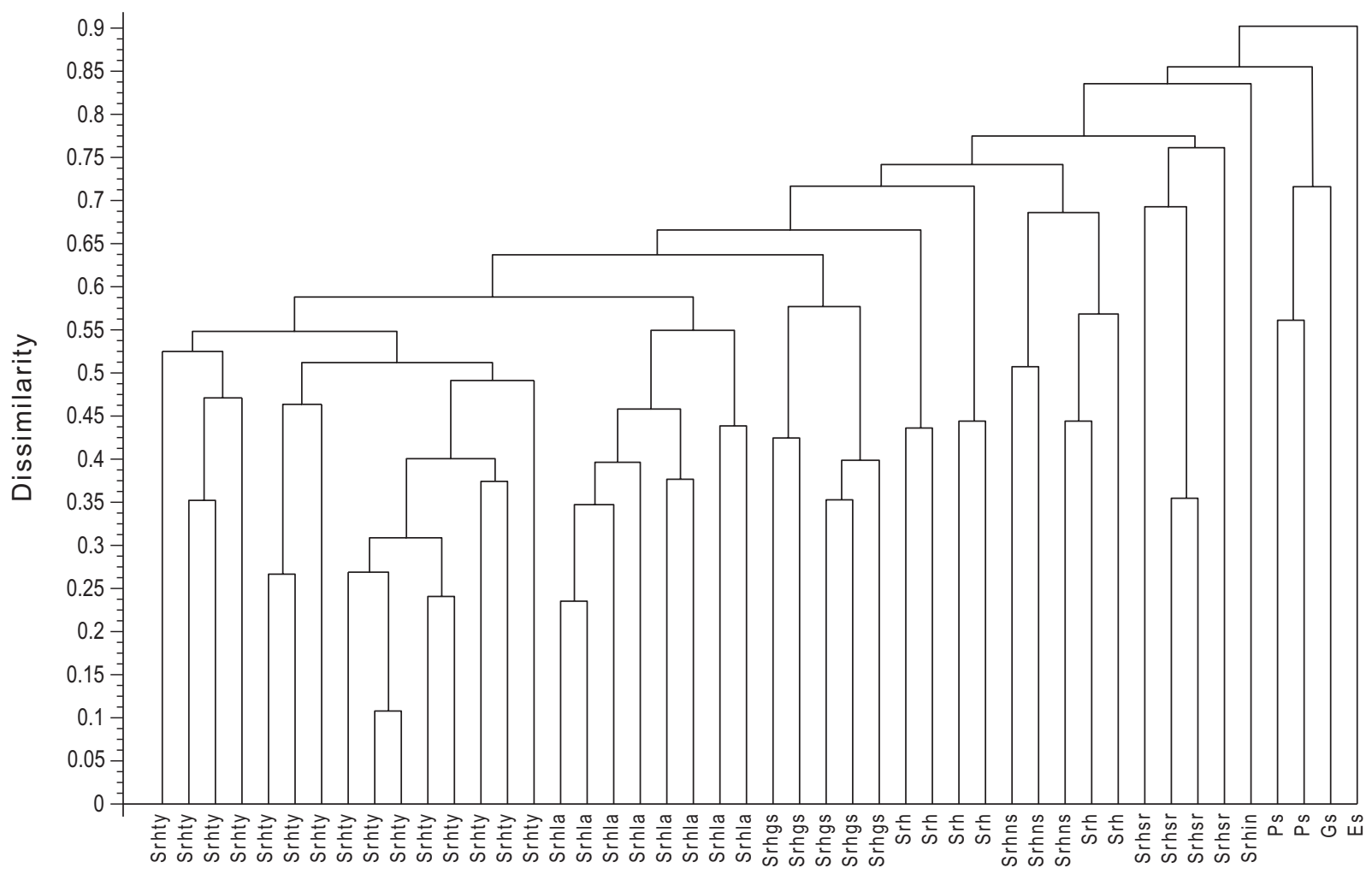

Legend /Legenda:

Srhty Salicetum retuso-herbaceae var. typica

Srhla Salicetum retuso-herbaceae var. Luzula alpinopilosa

Srhgs Salicetum retuso-herbaceae var. Gnaphalium supinum

Srhns Salicetum retuso-herbaceae var. Nardus stricta

Srhsr Salicetum retuso-herbaceae var. Salix retusa prov.
Srh Salicetum retuso-herbaceae s. lat.

Srhin Salicetum retuso-herbaceae initial stand

Ps Polytrichetum sexangularis

Gs Gnaphalium supinum community

Es Salici herbaceae-Eriophoretum scheuchzeri nom. prov.

(Salix herbacea-Eriophorum scheuchzeri community)

Figure 2: Dendrogram of alpine snow-bed communities with dominant Salix herbacea from the Julian Alps UPGMA, complement of similarity ratio

Slika 2: Dendogram alpinskih združb snežnih dolinic s prevladujočo vrsto Salix herbacea v Julijskih Alpah, UPGMA, komplement Wishartovega koeficienta podobnosti 

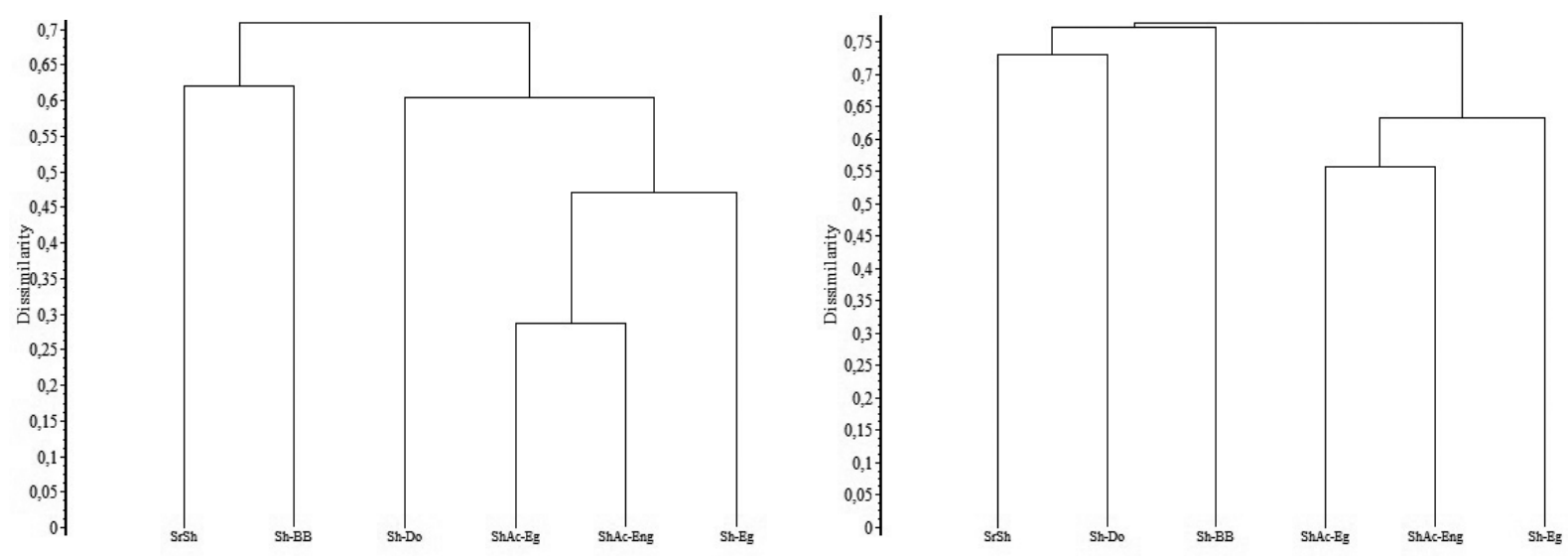

Legend to Figures 3 and 4 / Legenda k slikam 3 in 4

SrSh Salicetum retuso-herbaceae, Julian Alps, this article, relevés 1-23 in Table 1

Sh-Do Salicetum herbaceae, Dolomites, E. Pignatti \& S. Pignatti (2014, 2016: Association Table 12.3);

Sh-BB: Salicetum herbaceae, Central Alps, Braun-Blanquet \& Jenny 1926, Table VI, Columns 13-24;

Sh-Eg Salicetum herbaceae, Ammergauer Alps, Eastern Alps, Eggensberger 1994, Table 15, Columns 28-30;

ShAc-Eg Arabidetum caeruleae salicetosum herbaceae, Ammergauer Alps, Eastern Alps, Eggensberger 1994, Table 15, Columns 21-27;

ShAc-Eng Salici herbaceae-Arabidetum caeruleae var. Pritzelago alpina-Salix retusa, Eastern Alps, Englisch 1999: Table E, Columns 40-70.

Figure 3: Dendrogram of alpine snow-bed communities with dominant Salix herbacea from Central, Southern and Eastern Alps, UPGMA, complement of similarity ratio

Slika 3: Dendogram alpinskih združb snežnih dolinic s prevladujočo vrsto Salix herbacea v Centralnih, Južnih in Vzhodnih Alpah, UP-

GMA, komplement Wishartovega koeficienta podobnosti

Hierarchical classification based on species constancy demonstrated that the relevés from the Julian Alps are the most similar to the relevés from the Central Alps. If we take into account only the presence and absence of species, our relevés are the most similar to the relevés of the dwarf willow community from the Dolomites. However, floristic similarity is low, less than $30 \%$ according to Jaccard and 43\% according to Sørensen (1948). Floristic similarity with the stands of the association Salicetum herbaceae from the Central Alps is even lower, less than 25\% according to Jaccard. Although they share several species (Salix retusa, Silene acaulis), the communities with Salix herbacea from the Southern and Eastern Alps, which are distributed in the mountains with predominantly limestone bedrock, are floristically very different from the studied community from the Julian Alps, which means that our relevés cannot be classified either into the association Salici herbaceaeArabidetum caeruleae or into similar snow-bed communities on limestone bedrock. Two interesting snow-bed communities have been described in the southeastern part of the Italian Alps (Venetian Prealps, Vette di Feltre). One of them was classified into the association Potentillo dubiae-Homogynetum discoloris Aichinger 1933, but without Homogyne discolor (Giovagnoli \& Tasinazzo
Figure 4: Dendrogram of alpine snow-bed communities with dominant Salix herbacea from Central, Southern and Eastern Alps, UPGMA, complement of Jaccard's index

Slika 4: Dendogram alpinskih združb snežnih dolinic s prevladujočo vrsto Salix herbacea v Centralnih, Južnih in Vzhodnih Alpah, UPGMA, komplement Jaccardovega indeksa podobnosti

2004: 101-103), another into the subassociation Salicetum herbaceae potentilletosum brauneanae (Tomaselli et al. 2005: 126-127). The dominant vascular plant species are Salix herbacea, Salix retusa and S. reticulata in the first community and Salix herbacea, Luzula alpinopilosa and Leontodon hispidus in the second (with Salix retusa in one of five relevés). However, floristic similarity with the researched community in the Julian Alps is low, with Sørensen index only 34\% with Potentillo dubiae-Homogynetum discoloris and $40 \%$ with Salicetum herbaceae potentilletosum brauneanae.

The analysis of the synoptic table (Table 2) shows certain floristic specifics of the stands of the association Salicetum herbaceae s. lat. from the Julian Alps. These mainly include moss species Kiaeria falcata, Pohlia obtusifolia, Scapania helvetica, Sciuro-hypnum starkei, Barbilophozia lycopodioides, Bartramia ithyphylla, which are either very rare in the compared communities or were not recorded at all. However, given that mosses were largely ignored in past publications we cannot exclude the possibility that some of these species occur also in the compared communities. E. Pignatti \& S. Pignatti (2016: Association Table 12.3), for example, listed only Polytrichum alpinum, Polytrichum sp. and undetermined mosses with an important cover value in their table. 
Salix retusa occurs in the relevés from the Julian Alps, the Dolomites and the Eastern Alps. Our relevés comprise a few more species of the class Juncetea trifidi and some of them (Juncus jacquinii, Geum montanum and Euphrasia pulchella) were not recorded in the compared communities. Differential for the studied stands from the Julian Alps is Homogyne discolor, an eastern AlpineIllyrian species of subalpine-alpine grasslands on calcareous bedrock.

The analysis of proportions of diagnostic species ( $\mathrm{Ta}$ ble 3) indicates that the relevés of the community from the Julian Alps have comparatively the highest proportion of the species of the class Juncetea trifidi and a very small proportion of species of the class Thlaspietea rotundifolii. Compared to the community from the Central Alps this community comprises a higher proportion of species from the class Elyno-Seslerietea and a smaller proportion of species of the class Salicetea herbaceae and order Androsacetalia alpinae. Compared to the Dolomite community the stands of the community from the Julian Alps comprise a higher proportion of species of the class Salicetea herbaceae and a substantially lower proportion of species of the order Arabidetalia caeruleae. Compared to the communities from the Eastern Alps the studied community comprises a substantially smaller proportion of scree species of the order Arabidetalia caeruleae and class Thlaspietea rotundifolii and a substantially higher proportion of species of the class Salicetea herbaceae.

The studied stands could be classified into the new geographical variant Salicetum herbaceae Rübel 1911 var. geogr. Homogyne discolor. However, the applicable Code of Phytosociological Nomenclature (Weber et al. 2000) does not employ the syntaxonomic rank of geographical variant nor does the new Code that is currently underway (Čarni, in litt.). Low floristic similarity between our relevés and relevés of the association Salicetum herbaceae from the Central Alps, the fact that Salix retusa occurs in most of our relevés and in some of them even with considerable medium cover, as well as comparison of groups of diagnostic species (Table 3) allow for a description of the new association Salicetum retuso-herbaceae. Its diagnostic species (character and differential species) are Salix herbacea, Salix retusa, Agrostis rupestris, Juncus jacquinii, Kiaeria falcata, Pohlia obtusifolia and Homogyne discolor. The new association is classified into the alliance Salicion herbaceae, order Salicetalia herbaceae and class Salicetea herbaceae. It could also be classified into the alliance Salici herbaceaeArabidion caeruleae, but our relevés comprise only six of the species that Englisch (1999: 171) designated as diagnostic for this alliance, of which two flowering plants -
Potentilla brauneana and Alchemilla fissa occur with only a low frequency (in Table 1 they are presented together with the character species of the order Arabidetalia caeruleae). Three mosses occur with a higher frequency: Polytrichum juniperinum, Sanonia uncinata and Oncophorus virens. The ecological optimum of Polytrichum juniperinum and Sanionia uncinata is in the montane belt and higher, but they are distributed in the larger part of Slovenia, including the hill belt. Oncophorus virens commonly occurs at the elevations of $1,200 \mathrm{~m}$ and higher. It is the most frequent in the subalpine and alpine belts, but occurs in very diverse communities. We believe these three moss species are not relevant character species of a special group of alpine snow-bed communities, so they are presented in Table 1 with other moss species that were not determined in terms of phytosociology.

In terms of diagnostic species of the new association we can ascertain certain similarity with the association Homogyno discoloris-Salicetum retusae, but a comparison with the stands of this association in the Southeastern Alps (Aichinger 1933, Haderlapp 1982, Surina 2005) demonstrates distinct differences. The species that differentiate the association Salicetum retuso-herbaceae against the association Homogyno discoloris-Salicetum retusae are diagnostic species of classes Salicetea herbaceae and Juncetea trifidi, in particular Salix herbacea, Luzula alpinopilosa, Gnaphalium supinum, Agrostis rupestris and Juncus jacquinii as well as several moss species.

\subsubsection{Division into lower syntaxonomic units}

The dendrogram in Figure 2 also shows the division into lower syntaxonomic units. For the time being they are described only at the rank of variants due to a lack of relevant differential species to describe subassociations. Relevés $1-15$ in Table 1 are treated as the typical variant (var. typica). Relevés 16-23 are classified into the variant Luzula alpinopilosa. These are the relevés in which this species, which occurs in most of the relevés, has the highest medium cover. Nevertheless, these stands cannot be classified into the association Luzuletum alpinopilosaes. lat. (Luzuletum spadiceae s. lat.). We compared the stands of the association Luzuletum alpinopilosae s. lat. from the Julian Alps (Dakskobler \& Poldini 2019), with the stands of the typical variant Salicetum retuso-herbaceae var. typica and the stands of the variant Salicetum retusoherbaceae var. Luzula alpinopilosa, and obtained the result shown in Figure 5, which clearly demonstrates the affinity of these relevés with the association Salicetum retuso-herbaceae. 

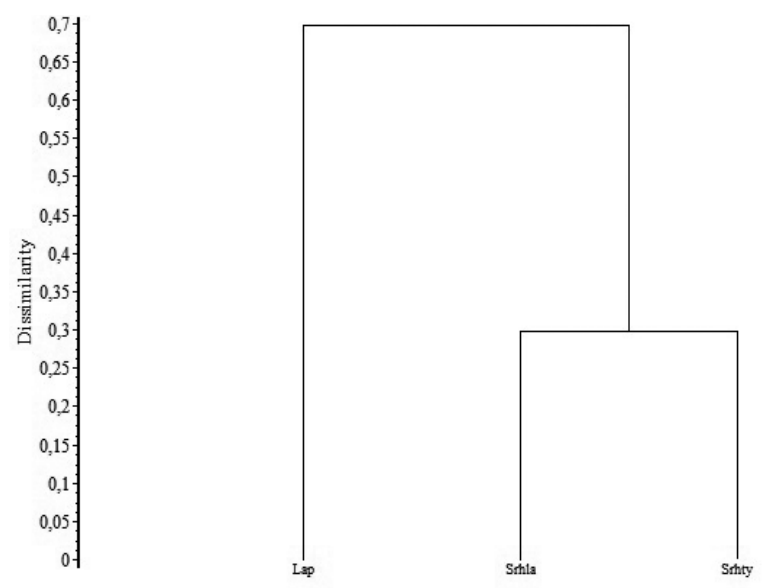

Legend/Legenda

Lap Luzuletum alpinopilosae s. lat., 15 relevés of I. Dakskobler and T. Wraber (Dakskobler \& Poldini 2019)

Srhla Salicetum retuso-herbaceae var. Luzula alpinopilosa, this article, relevés 16-23 in Table 1

Srhty Salicetum retuso-herbaceae var. typica, this article, table 1, relevés $1-15$

Figure 5: Dendrogram of communities with dominant Salix herbacea and (or) Luzula alpinopilosa in the Julian Alps, UPGMA, complement of similarity ratio

Slika 5: Dendrogram združb z dominantnima vrstama Salix herbaceae in (ali) Luzula alpinopilosa $\mathrm{v}$ Julijskih Alpah, UPGMA, komplement Wishartovega koeficienta podobnosti

Relevés 24-28 in Table 1 are classified into the variant Salicetum retuso-herbaceae var. Gnaphalium supinum. The diagnostic species of the association Salicetum retuso-herbaceae are very rare here and these stands and their floristic composition resemble also the stands of the association Nardo-Gnaphalietum supini. The diagnostic species of this association are Gnapablium supinum, Nardus stricta, Anthoxanthum nipponicum, Campanula scheuchzeri, Leontodon helveticus and Phleum rhaeticum (English 1993: 395). Our relevés mainly comprise only the first two species and due to their considerable similarity with other forms of the association Salicetum retuso-herbaceae (Figure 2 and Table 1) we provisionally decided to classify them into this association as a special variant. Its differential species are Gnaphalium supinum and Crepis aurea.

Relevés 29, 30 and 31 in Table 1 are tentatively treated as the syntaxon Salicetum retuso-herbaceae var. Nardus stricta, with relevés 29 and 30 bearing slight resemblance to the stands of the association Sieversio-Nardetum. Slightly similar to these three relevés is also relevé 32 . Their shared characteristic is the absence of Luzula al- pinopilosa. Character species of the association are well represented in relevés 33 to 37 , but because of certain floristic specifics these stands could be discussed only at the rank of association (sensu lato). Relevés 38-41, on the other hand, are more initial and indicate a higher similarity with the stands of the association Homogyno discolorisSalicetum retusae. Gnaphalium supinum and Homogyne discolor do not occur there and Luzula alpinopilosa is very rare. These relevés are tentatively classified into the variant with Salix retusa. Diagnostic species of the association Salicetum retuso-herbaceae are almost completely absent from relevés $42-45$, but only two of them - relevés 43 and 44 - can be classified into the association Polytrichetum sexangularis, whereas relevé 42 with a substantially higher number of flowering plants already indicates the initial form of the association Salicetum retuso-herbaceae. Relevé 45 is tentatively classified as a community with dominant Gnaphalium supinum (Gnaphalium supinum community). Relevé 46 is a community of alpine spring areas and classified into the provisional association Salici herbaceae-Eriophoretum scheuchzeri nom. prov. (Salix herbacea-Eriophorum scheuchzeri community), because its species composition does not allow it to be classified into the association Eriophoretum scheuchzeri Rübel 1911 (Steiner 1993: 144-145).

\subsection{Review of the studied syntaxa, including the type of newly described community}

\author{
Scheuchzerio palustris-Caricetea fuscae Tx. 1937 \\ Caricetalia fuscae Koch 1926 \\ Caricion fuscae Koch 1926 nom. conserv. propos. \\ Salici herbaceae-Eriophoretum scheuchzeri nom. prov. \\ Salicetea herbaceae Br.-Bl. 1948 \\ Salicetalia herbaceae Br.-Bl. in Br.-Bl. et Jenny 1926 \\ Salicion herbaceae Br.-Bl. in Br.-Bl. et Jenny 1926 \\ Salicetum retuso-herbaceae ass. nov. hoc loco; the no- \\ menclatural type, holotypus, is relevé 14 in Table 1. \\ Polytrichetum sexangularis Frey 1922 \\ Gnaphalium supinum community nom. prov.
}

\section{Conclusions}

Snow-bed communities with dominating Salix herbacea are very rare in the Julian Alps, which is largely associated with the predominantly calcareous bedrock. As a rule, they occur on small areas, mainly where the calcareous bedrock is interlayered with marlstone, claystone or chert and where the configuration of the terrain, long-lasting 
snow cover and soil conditions allow for the development of characteristic species of snow-bed communities on silicate bedrock, namely dwarf willow and Luzula alpinopilosa, Gnaphalium supinum, Soldanella pusilla, Sibbaldia procumbens, characteristic mosses (Bryopsida) and liverworts (Marchantiophyta): Anthelia juratzkana, Polytrichastrum sexangulare, Kiaeria falcata, Pohlia obtusifolia and Scapania helvetica. In the studied stands, especially those made under Mt. Mangart and on Mt. Plešivec in the Loška Stena rock wall, these character species of snow beds are accompanied also by character species of acidophilous alpine grasslands from the class Juncetea trifidi (Agrostis rupestris, Juncus jacquinii, Potentilla aurea, Leontodon helveticus, in places also Nardus stricta). Soil reaction in the studied communities is always acid ( $\mathrm{pH}$ 4.1-5.6). The species that are abundant and characteristic on nival soils on fine calcareous gravel are less frequent, with the exception of Salix retusa, Veronica alpina (which some authors classify among the character species of the class Salicetea herbaceae) and Taraxacum sect. Alpina. The only frequent species of subalpine-alpine grasslands, other than the widely distributed Polygonum viviparum, is Homogyne discolor, while Poa alpina and (partly) Crepis aurea are frequent among the species of nutrient-rich altimontane-subalpine grasslands and pastures. The full species composition of the recorded dwarf willow stands in the Julian Alps allows for their classification into the association Salicetum herbaceae at the rank of a new geographical variant with Homogyne discolor, but its full floristic inventory is nevertheless very different from the floristic inventory of this community in the Central and Eastern Alps and the Dolomites, which means that classification into the new association Salicetum retuso-herbaceae is also correct as it indirectly indicates the contact and affinity with snow-bed communities on calcareous gravel. The stands of the new association are extremely important as biotopes as they are sites of several Red-listed flowering and vascular plants (Anon. 2002, Annex 1): Astragalus australis, Coeloglossum viride, Eriophorum scheuchzeri, Elyna myosuroides, Helictotrichon versicolor, Juncus trifidus, Luzula alpinopilosa, Sedum alpestre, and especially mosses and liverworts (Anon. 2002, Annex 2): Anthellia juratzkana, Asterella lindenbergiana, Kiaeria starkei, Pohlia drummondii, Pohlia obtusifolia, Polytrichastrum sexangulare, Scapania helvetica, Sciuro-hypnum glaciale and Tortula mucronifolia. Vegetation of snow beds with Salix herbaceae under Mt. Mangart is indirectly threatened by grazing by small ruminants and (too) many tourists that visit the area in the summer; it is less threatened on Mt. Plešivec in Loška Stena and in the cirque $\mathrm{Na}$ Jezerih under the peaks of Rokavi.

\section{Povzetek}

\section{Združbe snežnih dolinic s prevladujočo vrsto Salix herbacea $v$ Julijskih Alpah}

Združbe snežnih tal oz. snežnih dolinic so v slovenskih Alpah vezane na območja, kjer sneg dolgo obleži in jih dolgo namaka snežnica (tla so dobro namočena s talečim se snegom). Najbolj značilne združbe v pravih snežnih dolinicah (razred Salicetea herbaceae) so razširjene samo v drobcih, tako združba norveškega lasastega kapičarja (Polytrichetum sexangularis $=$ Polytrichetum norvegicae $)$ in zelnate vrbe (Salicetum herbaceae s. lat.). Bolj razširjeni so sestoji več drugih ledeniških vrb in rastlin snežnih melišč (zveza Arabidion caeruleae). Združbo zelnate vrbe oz. njene sestoje poznamo pod Mangartom, v Škrlatiški skupini, na Kriških podih in na Stolu v Karavankah. Podrobno fitocenološko-ekološke raziskavo njenih sestojev v Julijskih Alpah sta opravila pokojni Tone Wraber (19382010) in Andrej Martinčič v začetku septembra 1968 v Škrlatiški skupini, v krnici $\mathrm{Na}$ jezerih ( $\mathrm{Na}$ jezeru) pod Visokim Rokavom in dve leti kasneje, začetek septembra 1970, pod Mangartom (na Mangartskem sedlu, v kotanji Prodi). Njuni popisi so bili podlaga za fitocenološko analizo $s$ hierarhično klasifikacijo in uvrstitev preučenih združb v sintaksonomski sistem. Na podlagi primerjav $s$ podobnimi združbami drugod v Centralnih, Južnih in Vzhodnih Alpah lahko večino preučenih sestojev vrednotimo kot novo geografsko varianto Salicetum herbaceae var. Homogyne dicolor ali kot novo asociacijo Salicetum retuso-herbaceae. Ker Kodeks fitocenološke nomenklature ranga geografske variante ne obravnava in ker primerjave (tabele 2 in 3) potrjujejo zadostne floristične razlike, smo se odločili za opis nove asociacije. Njene diagnostične vrste (značilnice in razlikovalnice) so Salix herbacea, Salix retusa, Agrostis rupestris, Juncus jacquinii, Kiaeria falcata, Pohlia obtusifolia in Homogyne discolor. Novo asociacijo uvrščamo v zvezo Salicion herbaceae, red Salicetalia herbaceae in razred Salicetea herbaceae. Razlikujemo več variant (var. typica, var. Luzula alpinopilosa, var. Gnaphalium supinum, var. Nardus stricta in var. Salix retusa), ki označujejo različne razvojne stopnje rastja snežnih tal na mešani karbonatno-silikatni podlagi $\mathrm{v}$ alpinskem pasu, kjer pa je reakcija tal vedno kisla ( $\mathrm{pH} 4,1-5,6)$. Le dva popisa s krnice $\mathrm{Na}$ jezerih lahko uvrstimo v najbolj pionirsko obliko, asociacijo Polytrichetum sexangularis, en popis s Prodov pod Mangartom pa v združbo alpinskega povirja Salici herbaceae-Eriophoretum scheuchzeri nom. prov. Združbe zelnate vrbe v Julijskih Alpah so z biotopskega vidika zelo pomembne, saj so rastišče nekaterih vrst iz rdečega seznama cvetnic in praprotnic (Anon. 2002, 
Priloga 1): Astragalus australis, Coeloglossum viride, Eriophorum scheuchzeri, Elyna myosuroides, Helictotrichon versicolor, Juncus trifidus, Luzula alpinopilosa, Sedum alpestre, še posebej pa mahov in jetrenjakov (Anon. 2002, Priloga 2): Anthellia juratzkana, Asterella lindenbergiana, Kiaeria starkei, Pohlia drummondii, Pohlia obtusifolia, Polytrichastrum sexangulare, Scapania helvetica, Sciuro-hypnum glaciale in Tortula mucronifolia. Vegetacijo snežnih dolinic z vrsto Salix herbaceae pod Mangartom posredno ogroža paša drobnice in predvsem (pre)velik turistični obisk $\mathrm{v}$ poletnem času, manj ogrožena je na Plešivcu v Loški steni in v krnici $\mathrm{Na}$ jezerih pod Rokavi.

\section{Acknowledgements}

We would like to thank the heirs of late Tone Wraber for giving his manuscripts and professional literature to the safekeeping of the Botanical Garden of the University of Ljubljana, and to its director, Dr. Jože Bavcon, who allowed us to examine professor's legacy. We owe special thanks to Dr. Branko Vreš, Mag. Andrej Seliškar and Brane Anderle, co-authors of Figure 1. Two anonymous reviewers helped us with valuable improvements and corrections. We also acknowledge the financial support from the Slovenian Research Agency (research core funding No. P1-0236). English translation by Andreja Šalamon Verbič.

\section{References}

Aeschimann, D., Lauber, K., Moser, D. M. \& Theurillat, J.-P. 2004: Flora alpina. Bd. 1, 2, 3. Haupt Verlag, Bern, Stuttgart, Wien, 1159 pp., 1188 pp, 322 pp.

Aichinger, E. 1933: Vegetationskunde der Karawanken. Gustav Fischer Verlag, Jena, 329 pp.

Anonymous 2002: Pravilnik o uvrstitvi ogroženih rastlinskih in živalskih vrst v rdeči seznam. Uradni list RS 82/2002.

Braun-Blanquet, J. 1964: Pflanzensoziologie. Grundzüge der Vegetationskunde. 3. Auflage. Springer, Wien - New York, 865 pp.

Braun-Blanquet, J. \& Jenny, J. 1926: Vegetationsentwicklung und Bodenbildung in der alpinen Stufe der Zentralalpen. Denkschr. Schweiz. Naturforsch. Ges. Zürich 63: 183-349.

Buser, S. 2009: Geološka karta Slovenije 1: 250.000. Geological map of Slovenia 1: 250,000. Geološki zavod Slovenije, Ljubljana.

Cegnar, T. 1998: Temperatura zraka. In: Fridl, J., Kladnik, D., Orožen Adamič, M. \& Perko, D. (eds.): Geografski atlas Slovenije. Država v prostoru in času. Državna založba Slovenije, Ljubljana, pp. 100-101.

Dakskobler, I. \& Poldini, L. 2019: Alpine grasslands with dominant Luzula alpinopilosa in the Julian and Carnic Alps (NW Slovenia, NE Italy). Hacquetia - in review.
Eggensberger, P. 1994: Die Pflanzengesellschaften der subalpinen umd alpinen Stufe der Ammergauer Alpen und ihre Stellung in den Ostalpen. Ber. Bayer. Bot. Ges., Beihefte 8: 3-239.

Englisch, T. 1993: Salicetea herbaceae. In: Mucina, L., Grabherr, G. \& Ellmauer, T. (eds.): Die Pflanzengesellschaften Österreichs. Teil II. Gustav Fischer Verlag, Jena. pp. 389-399.

Englisch, T. 1999: Multivariate Analysen zur Synsystematik und Standortsökologie der Schneebodenvegetation (Arabidetalia caerulae) in den Nördlichen Kalkalpen. Stapfia 59, 211 pp. + Tables.

Giovagnoli, L. \& Tasinazzo, S. 2014: The dolina system vegetation of the northern glacio-karst sector of the Asiago Plateau (Venetian Prealps - NE Italy). Plant Sociology 51 (2): 83-116.

Grabherr, G. \& Mucina, L. (eds.) 1993: Die Pflanzengesellschaften Österreichs. Teil II: Natürliche waldfreie Vegetation. Gustav Fischer Verlag, Jena - Stuttgart - New York. 523 pp.

Haderlapp, P. 1982: Alpine Vegetation Der Steiner Alpen. Carinthia II 40: 3-56.

Hegi, G., Merxmüller, H. Reisigl, H. 1980: Alpska flora. Prevedel in dopolnil T. Wraber. Državna založba Slovenije, Ljubljana, 223 pp.

Maarel van der, E. 1979: Transformation of cover-abundance values in phytosociology and its effects on community similarity. Vegetatio 39 (2): 97-114.

Martinčič, A., Wraber, T., Jogan, N., Podobnik, A., Turk, B., Vreš, B., Ravnik, V., Frajman, B., Strgulc Krajšek, S., Trčak, B., Bačič, T., Fischer, M. A., Eler, K. \& Surina, B. 2007: Mala flora Slovenije. Ključ za določanje praprotnic in semenk. Četrta, dopolnjena in spremenjena izdaja. Tehniška založba Slovenije, Ljubljana, 967 pp.

Mucina, L., Bültmann, H., Dierßen, K., Theurillat, J.-P., Raus, T., Čarni, A., Šumberová, K., Willner, W., Dengler, J., Gavilán García, R., Chytrý, M., Hájek, M., Di Pietro, R., Iakushenko, D., Pallas, J., Daniëls, F. J. A., Bergmeier, E., Santos Guerra, A., Ermakov, N., Valachovič, M., Schaminée, J. H. J., Lysenko, T., Didukh, Y. P., Pignatti, S., Rodwell, J. S., Capelo, J., Weber, H. E., Solomeshch, A., Dimopoulos, P., Aguiar, C., Hennekens, S. M. \& Tichý, L. 2016: Vegetation of Europe: hierarchical floristic classification system of vascular plant, bryophyte, lichen, and algal communities. Applied Vegetation Science 19, Suplement 1: 3-264.

Oberdorfer E. 1992: Klasse Salicetea herbaceae Br.-Bl. et al. 47. In: Oberdorfer E. (ed.): Süddeutsche Pflanzengesellschaften, 3. Aufl. Teil 1, Gustav Fischer Verlag, Jena. pp. 214-220.

Pignatti, E. \& Pignatti, S. 2014: Plant Life of the Dolomites. Vegetation Structure and Ecology. Publication of the Museum of Nature South Tyrol Nr. 8, Naturmuseum Südtirol, Bozen, Springer Verlag, Heidelberg, 769 pp.

Pignatti, E. \& Pignatti, S. 2016: Plant Life of the Dolomites. Vegetation Tables. Publication of the Museum of Nature South Tyrol Nr. 11, Bozen, Springer Verlag, Heidelberg, 575 pp.

Podani, J. 2001: SYN-TAX 2000. Computer Programs for Data Analysis in Ecology and Systematics. User's Manual, Budapest, 53 pp.

Ros, R.M., Mazimpaka, V., Abou-Salama, U., Aleffi, M., Blockeel, T.L., Brugués, M., Cano, M.J., Cros, R.M., Dia, M.G., Dirkse, G.M., El Saadawi, W., Erdağ, A., Ganeva, A., González-Mancebo, J.M., Hernstadt, I., Khalil, K., Kürschner, H., Lanfranco, E., LosadaLima, A., Refai, M.S., Rodríguez-Nunez, S., Sabovljević, M., Sérgio, C., Shabbara, H., Sim-Sim, M. \& Söderström, M. 2007: Hepatics 
and Anthocerotes of the Mediterranean, an annotated checklist. Cryptogamie, Bryologie 28 (4): 351-437.

Ros, R.M., Mazimpaka, V., Abou-Salama, U., Aleff, M., Blockeel, T.L., Brugués, M., Cros, R.M., Dia, M.G., Dirkse, G.M., Draper, I., El Saadawi, W., Erdağ, A., Ganeva, A., Gabriel, R., GonzálezMancebo, J.M., Hernstadt, I., Hugonnot, V., Khalil, K., Kürschner, H., Losada-Lima, A., Luís, L., Mifsud, S., Privitera, M., Puglisi, M., Sabovljević, M., Sérgio, C., Shabbara, H.M., Sim-Sim, M., Sotiaux, A., Tacchi, R., Vanderpoorten, A. \& Werner, O. 2013: Mosses of the Mediterranean, an annotated checklist. Cryptogamie, Bryologie 34 (2) 99-283.

Seliškar, T., Vreš, B. \& Seliškar, A. 2003: FloVegSi 2.0. Računalniški program za urejanje in analizo bioloških podatkov. Biološki inštitut ZRC SAZU, Ljubljana.

Sørensen, Th. 1948: A method of establishing groups of equal amplitude in plant sociology based on similarity of species content. Det Kongelige Danske Videnskaberns Selskab, Biologiske Skrifter 5 (4): $1-34$.

Steiner, G. M. 1993: Scheuchzerio-Caricetea fuscae. In: G. Grabherr \& L. Mucina (eds.): Die Pflanzengesellschaften Österreichs. Teil II: Natürliche waldfreie Vegetation. Gustav Fischer Verlag, Jena - Stuttgart - New York, pp. 131-165.

Suppan, U., Prügger, J. \& Mayrhofer, H. 2000: Catalogue of the lichenized and lichenicolous fungi of Slovenia. Bibliotheca Lichenologica 76: 1-215.

Surina, B. 2005: Subalpinska in alpinska vegetacija Krnskega pogorja v Julijskih Alpah. Scopolia 57: 1-122.

Šilc, U. \& Čarni, A. 2012: Conspectus of vegetation syntaxa in Slovenia. Hacquetia 11 (1): 113-164.

Theurillat, J.-P. 2004: Pflanzensociologisches System. In: Aeschimann, D., Lauber, K., Moser, D. M. \& Theurillat, J.-P.: Flora alpina, 3.

Haupt Verlag, Bern, Stuttgart, Wien, pp. 301-313.
Tomaselli, M., Petraglia, A., Lasen, C. 2005: Flora briologica e vegetazione delle vallette nivali nelle Vette di Feltre (Parco nazionale Dolomiti Bellunesi, Italia settentrionale). Gortania 26 (2004): 111-136.

Vidic, N. J., Prus, T., Grčman, H., Zupan, M., Lisec, A., Kralj, T., Vrščaj, B., Rupreht, J., Šporar, M., Suhadolc, M., Mihelič, R. \& Lobnik, F. 2015: Tla Slovenije s pedološko karto v merilu 1: 250 000. Soils of Slovenia with soil map 1: 250 000. European Union \& University of Ljubljana, Luxemburg, Ljubljana, 152 pp. + maps.

Vrščaj, B., Repe, B., Simončič, P. 2017: The Soils of Slovenia. Springer, Dordrecht, 216 pp.

Weber, H. E., J. Moravec, J. P. Theurillat 2000: International Code of Phytosociological Nomenclature. 3rd. Edition. Journal of Vegetation Science 11 (5): 739-766.

Wirth, V. 1995: Flechtenflora. 2. Auf. Verlag Eugen Ulmer, Stuttgart, $661 \mathrm{pp}$.

Wraber, T. 1972: Contributo alla conoscenza della vegetazione pioniere (Asplenietea rupestria e Thlaspeetea rotundifolii) delle Alpi Giulie. Tesi di laurea. Università degli Studi di Trieste, Facoltà di Scienze, Trieste. $81 \mathrm{pp}$.

Wraber, T. 1996a: Združbe skalnih razpok, melišč, rečnih prodišč, snežnih dolinic, visokogorskih resav in travišč. In: Gregori, J. et al. (eds.): Narava Slovenije, stanje in perspektive: Zbornik prispevkov o naravni dediščini Slovenije. Društvo ekologov Slovenije, Ljubljana. pp. 107-112.

Wraber, T. 1996b: Rastlinstvo. Enciklopedija Slovenije 10 (Pt-Savn), str. 85-93, Mladinska knjiga, Ljubljana.

Zupančič, B. 1998: Padavine. In: Fridl, J., Kladnik, D., Orožen Adamič, M. \& Perko, D. (eds.): Geografski atlas Slovenije. Država v prostoru in času. Državna založba Slovenije, Ljubljana, pp. 98-99. 


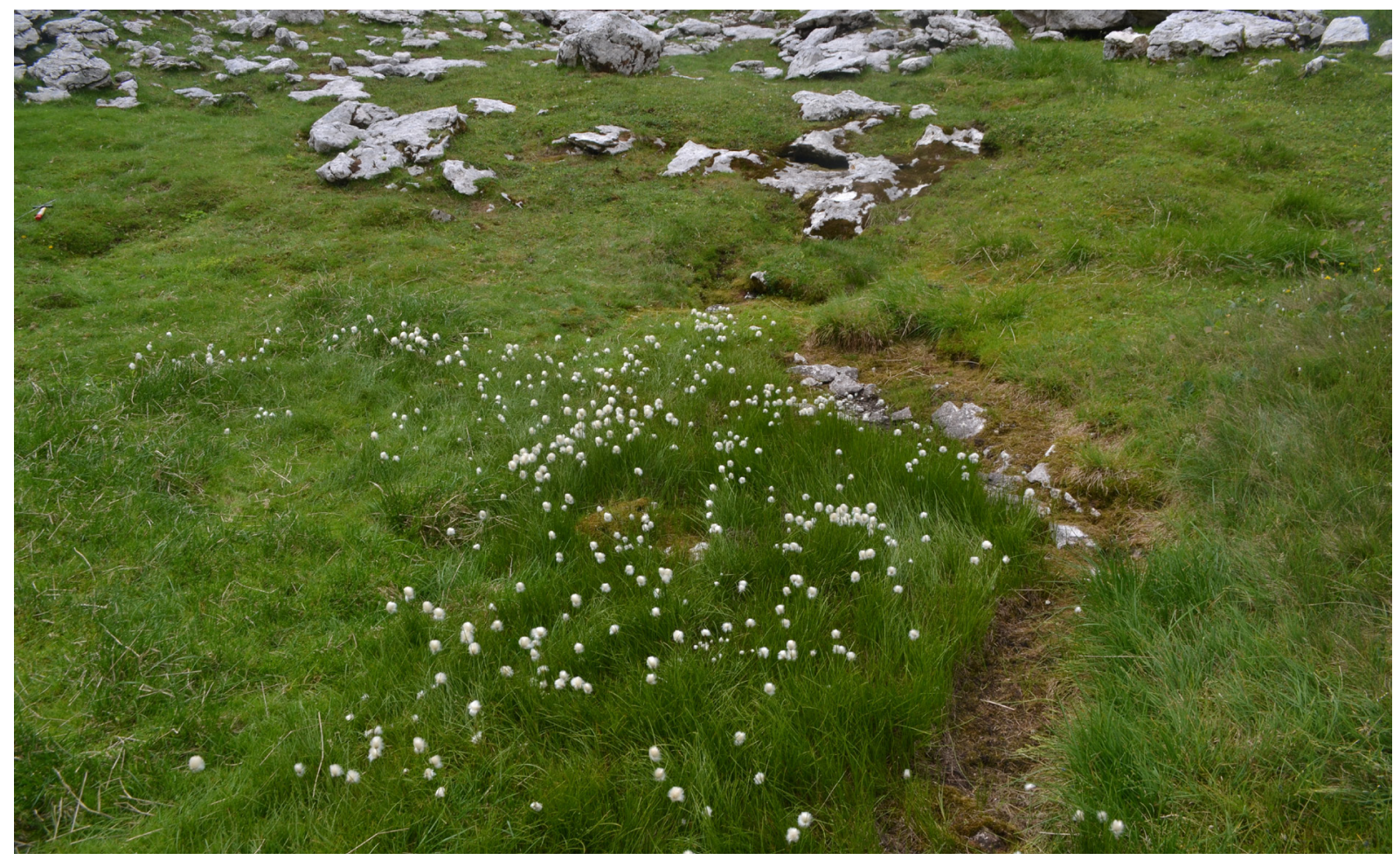

Figure 6: Snow-bed vegetation with Eriophorum scheuchzeri and Salix herbacea, Prodi below Mt. Mangart. Photo: I. Dakskobler. Slika 6: Rastje snežnih dolinic z vrstama Eriophorum scheuchzeri in Salix herbacea, Prodi pod Mangartom. Foto: I. Dakskobler.

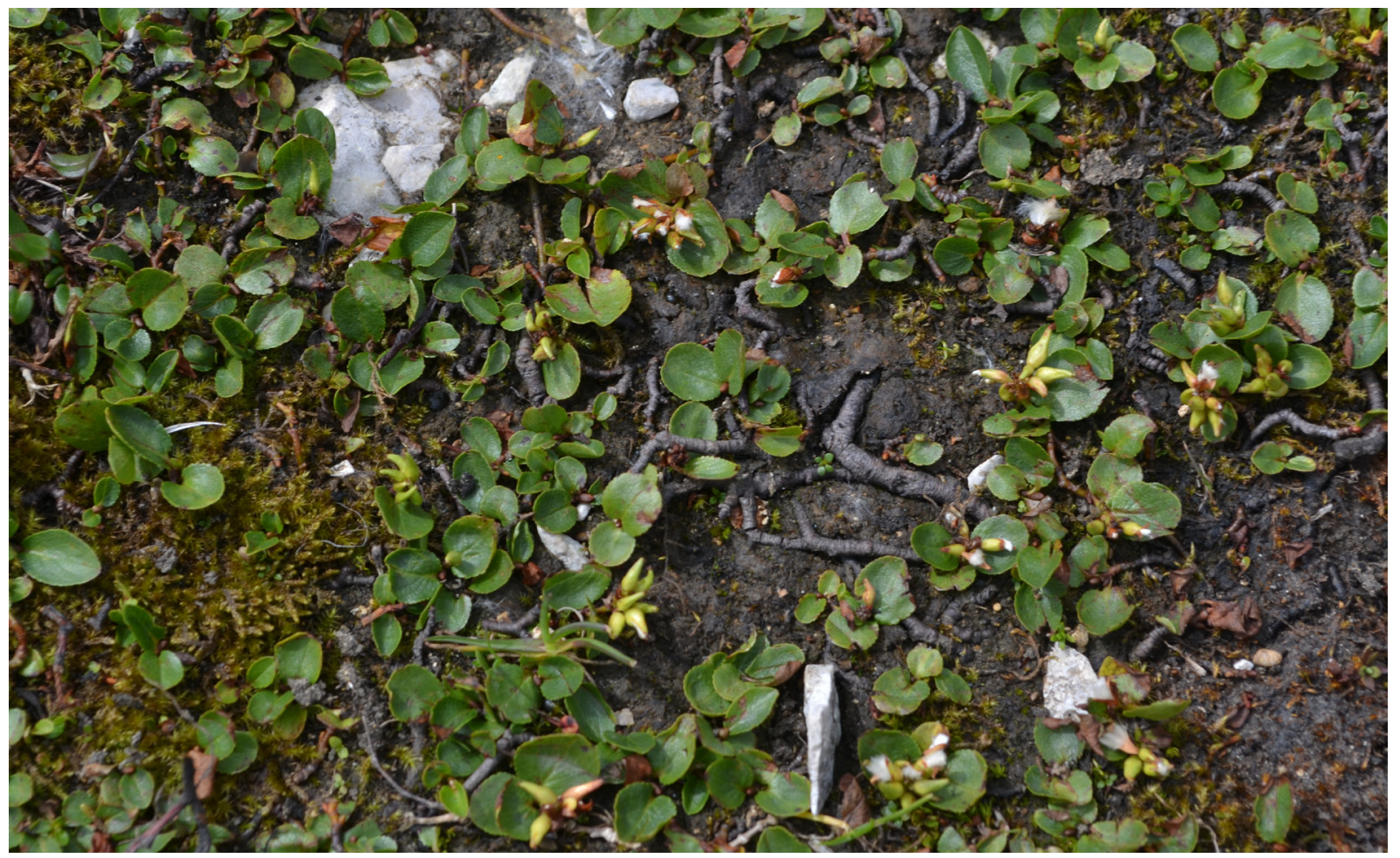

Figure 7: Stand of the association Salicetum retuso-herbaceae, Na Jezerih below Mt. Visoki Rokav. Photo: I. Dakskobler.

Slika 7: Sestoj asociacije Salicetum retuso-herbaceae, Na jezerih pod Visokim Rokavom. Foto: I. Dakskobler. 
Table 1: Snow-bed communities with Salix herbacea in the Julian Alps

Tabela 1: Združbe snežnih dolinic z vrsto Salix herbacea v Julijskih Alpah

\section{Number of relevé (Zaporedna številka popisa)}

Database number of relevé (Delovna številka popisa)

Acronym of syntaxa (Akronim za sintaksone)

Author of the relevé (Avtor popisa)

Elevation in $\mathrm{m}$ (Nadmorska višina $\mathrm{v} \mathrm{m})$

Aspect (Lega)

Slope in degrees (Nagib v stopinjah)

Parent material (Matična podlaga)

Soil (Tla)

Stoniness in \% (Kamnitost v \%)

Cover of herb layer in \% (Zastiranje zeliščne plasti v \%): $\quad$ E1

Cover of moss layer in \% (Zastiranje mahovne plasti v \%) E0

Number of species (Število vrst)

Relevé area (Velikost popisne ploskve)

Date of taking relevé (Datum popisa)

Locality (Nahajališče)

Quadrant (Kvadrant)

Coordinate GK Y (D-48)

Coordinate GK X (D-48)

\section{Diagnostic sp}

Salix herbacea

AC Salix retusa

JT Agrostis rupestris

JT Juncus jacquinii

SH Kiaeria falcata

$\mathrm{SH}$ Pohlia obtusifolia

ES Homogyne discolor $\mathrm{m}^{2}$ $\begin{array}{lllllllllllllllll}1 & 2 & 3 & 4 & 5 & 6 & 7 & 8 & 9 & 10 & 11 & 12 & 13 & 14 & 15 & 16\end{array}$

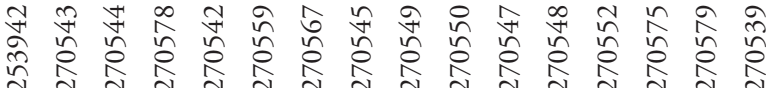

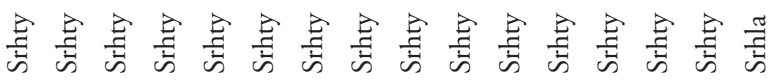

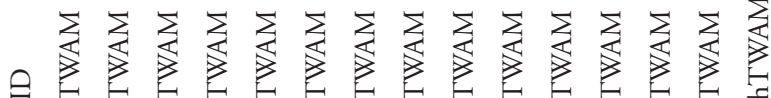

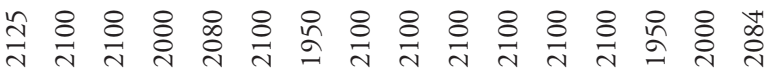
$\begin{array}{llllllllllllllll}\mathrm{N} & \mathrm{N} & \mathrm{N} & \mathrm{E} & \mathrm{N} & \mathrm{N} & \mathrm{E} & \mathrm{N} & \mathrm{N} & \mathrm{N} & \mathrm{N} & \mathrm{N} & \mathrm{N} & \mathrm{N} & \mathrm{S} & \mathrm{N}\end{array}$ $\begin{array}{llllllllllllllll}10 & 5 & 5 & 3 & 15 & 10 & 4 & 10 & 5 & 2 & 5 & 5 & 15 & 2 & 15 & 20\end{array}$

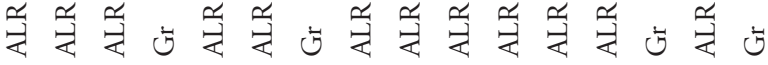

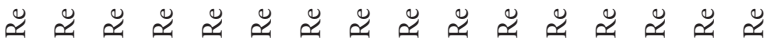
. . 5. . . . . 1020 . .

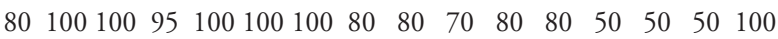
$\begin{array}{llllllllllllllll}20 & 15 & 20 & 15 & 10 & 50 & 10 & 20 & 70 & 70 & 50 & 50 & 50 & 30 & 50 & 10\end{array}$ $\begin{array}{llllllllllllllll}30 & 30 & 27 & 23 & 24 & 16 & 22 & 27 & 22 & 21 & 27 & 22 & 24 & 25 & 25 & 26\end{array}$ $\begin{array}{llllllllllllllll}10 & 1,5 & 1,5 & 2 & 1 & 2 & 1 & 1 & 1 & 1 & 1 & 1 & 2 & 2 & 2 & 2\end{array}$

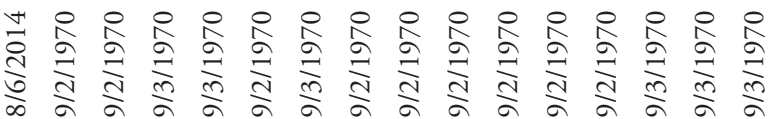

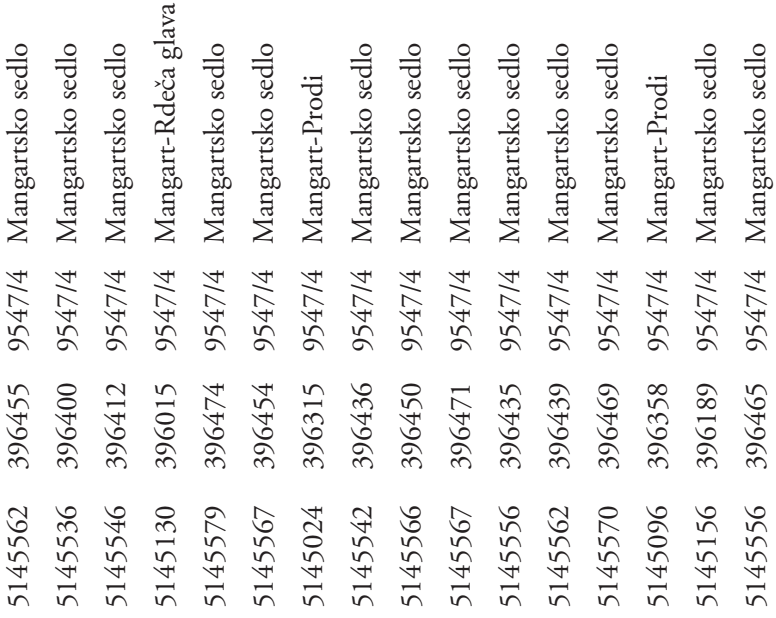
te asociacije)

\begin{tabular}{l|cccccccccccccccc} 
E1 & 3 & 2 & 1 & 2 & 4 & 5 & 2 & 1 & 1 & 1 & 1 & 1 & 3 & 2 &. & 1 \\
E1 & 1 & + & 2 & 2 & 1 & + &. & 2 & 2 & 2 & 2 & 1 & 1 & + & + & 1 \\
E1 & + & 1 & 1 & 1 & + & 1 & + & 1 & 1 & 1 & 1 & 1 & 1 & 1 & + & + \\
E1 &. & + & + & 1 & + & + & + & 1 & + & + & 1 & + &. & + & 1 & + \\
E0 & 1 &. & 1 &. & 1 & 3 & 1 & 1 & 1 & + & 1 & 1 & 1 & 1 & 3 & + \\
E0 &. & + & + & + & 1 &. & + &. & + & + & + &. &. & + & + &. \\
E1 & 1 & + &. &. &. &. &. & 1 & 1 & + & + &. &. & + &. & + \\
\cline { 2 - 11 }
\end{tabular}


\begin{tabular}{lllllll|lllllllllllllllllllllll}
17 & 18 & 19 & 20 & 21 & 22 & 23 & 24 & 25 & 26 & 27 & 28 & 29 & 30 & 31 & 32 & 33 & 34 & 35 & 36 & 37 & 38 & 39 & 40 & 41 & 42 & 43 & 44 & 45 & 46
\end{tabular}

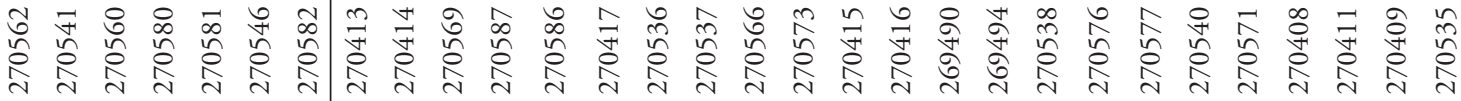

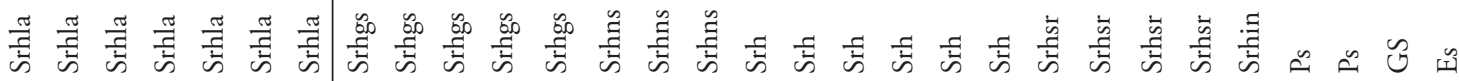

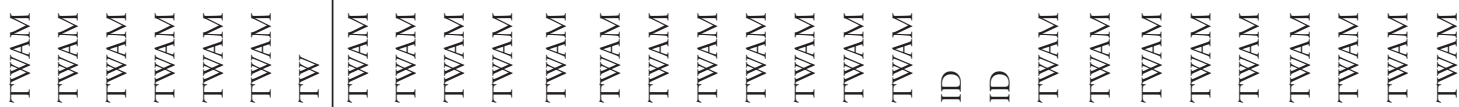

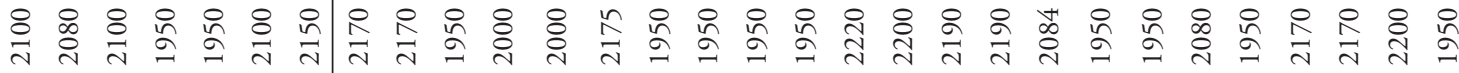
\begin{tabular}{lllllll|lllllllllllllllllllllll}
$\mathrm{N}$ & $\mathrm{N}$ & $\mathrm{N}$ & $\mathrm{N}$ & 0 & $\mathrm{~N}$ & $\mathrm{~N}$ & $\mathrm{E}$ & 0 & 0 & W SSW & $\mathrm{E}$ & $\mathrm{N}$ & 0 & $\mathrm{E}$ & 0 & SE & $S$ & $\mathrm{~S}$ & $\mathrm{~N}$ & 0 & $\mathrm{NW}$ & $\mathrm{N}$ & $\mathrm{N}$ & 0 & 0 & 0 & 0 & 0
\end{tabular} $\begin{array}{llllllllllllllllllllllllllllll}20 & 15 & 2 & 10 & 0 & 20 & 30 & 2 & 0 & 0 & 15 & 20 & 2 & 2 & 0 & 1 & 0 & 2 & 3 & 25 & 10 & 0 & 5 & 3 & 30 & 0 & 0 & 0 & 0 & 0\end{array}$

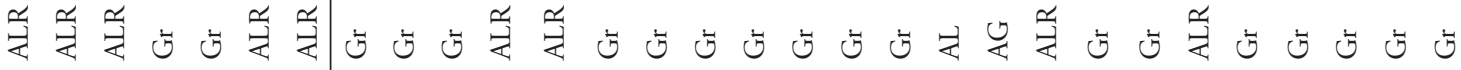

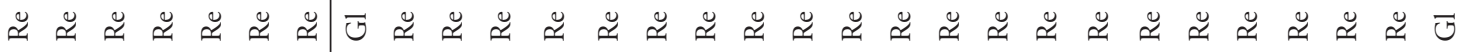
$10010010010010010095 \quad 90 \quad 5010095 \quad 9010010010010010070 \quad 70 \quad 809010010010010090 \quad 25 \quad 20 \quad 50100$ \begin{tabular}{lllllll|llllllllllllllllllllll}
5 & 15 & 10 & 20 & 20 & 5 & 5 & 2 & 40 & 15 & 10 & 15 & 5 & 15 & 30 & 30 & 60 & 30 & 25 & 20 & 10 & 5 & 5 & 15 & 15 & 50 & 75 & 70 & 20
\end{tabular}

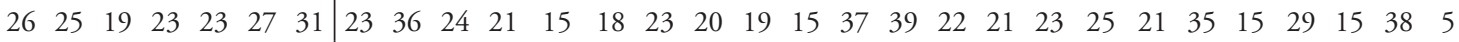
$\begin{array}{llllllllllllllllllllllllllllll}2 & 1 & 2 & 2 & 2 & 1 & 20 & 2 & 8 & 1 & 2 & 2 & 6 & 1 & 1 & 1 & 1 & 6 & 10 & 4 & 2 & 2 & 1 & 1 & 2 & 1,5 & 4 & 15 & 6 & 1\end{array}$

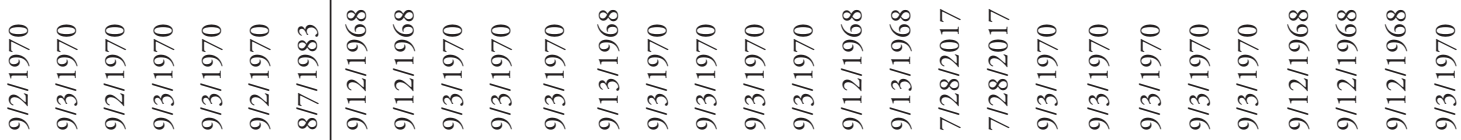

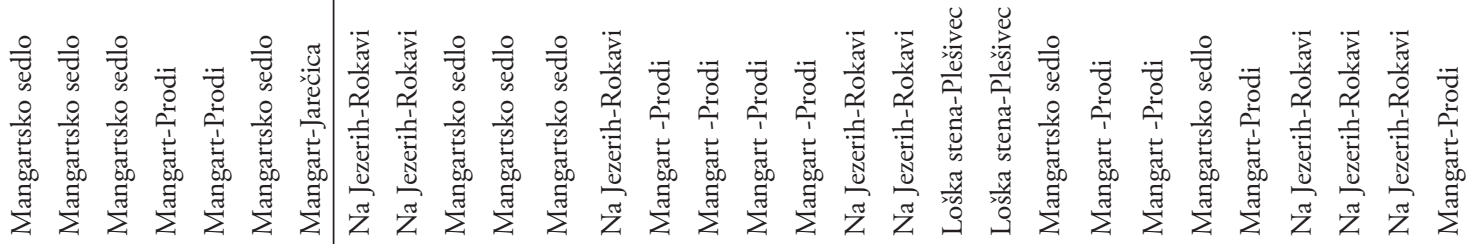

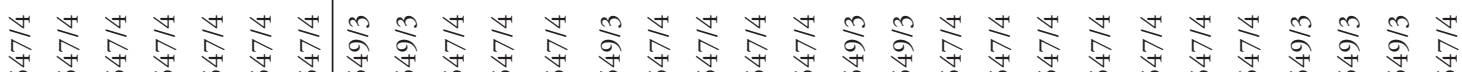

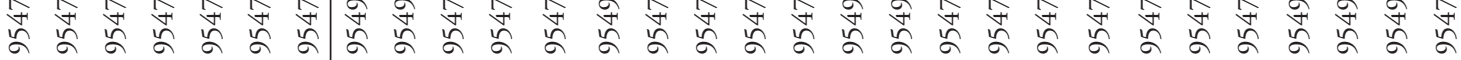

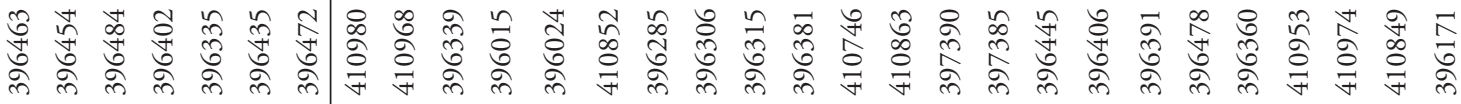

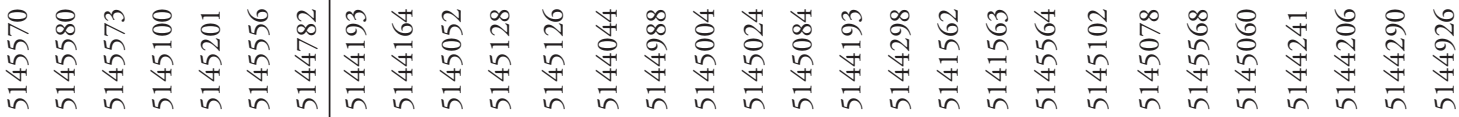

\begin{tabular}{|c|c|c|c|c|c|c|c|c|c|c|c|c|c|c|c|c|c|c|c|c|c|c|c|c|c|}
\hline+ & + & . & + & 2 & + & 2 & 2 & 2 & . & . & . & + & 2 & 4 & 2 & 5 & + & 1 & 3 & 2 & 2 & 2 & 2 & 1 & + \\
\hline+ & 1 & 1 & + & 1 & 3 & 4 & . & . & + & + & . & . & . & + & . & . & + & + & . & . & + & 2 & 1 & 4 & $\cdot$ \\
\hline+ & + & 2 & + & + & + & 1 & . & . & + & + & 1 & 1 & . & . & . & . & + & 2 & 2 & 1 & 1 & 1 & 2 & . & $\cdot$ \\
\hline+ & . & + & . & $\cdot$ & 1 & + & . & $\cdot$ & . & $\cdot$ & . & . & . & . & . & . & . & . & 2 & 1 & . & 2 & 1 & 1 & . \\
\hline$\cdot$ & + & + & + & . & . & $\cdot$ & 1 & . & + & + & $\cdot$ & . & . & . & . & $\cdot$ & . & . & · & . & $\cdot$ & . & . & . & . \\
\hline$\cdot$ & 1 & $\cdot$ & + & $\cdot$ & . & $\cdot$ & . & $\cdot$ & + & . & + & · & . & + & . & . & . & . & . & . & + & · & . & . & . \\
\hline+ & . & . & . & . & 2 & 1 & + & . & . & . & . & $\cdot$ & . & . & . & . & + & 2 & r & 1 & . & r & . & . & 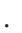 \\
\hline
\end{tabular}


Number of relevé (Zaporedna številka popisa)

Salicetea herbaceae

SH Gnaphalium supinum

SH Soldanella pusilla

SH Luzula alpinopilosa

$\mathrm{SH}$ Sibbaldia procumbens

$\mathrm{SH}$ Sagina saginoides

SH Anthelia juratzkana

SH Polytrichastrum sexangulare

SH Scapania helvetica

SH Sciuro-hypnum glaciale*

SH Kiaeria starkei

SH Pohlia drummondii

SH Asterella lindenbergiana

AA Androsacetalia alpinae

Oxyria digyna

Sedum alpestre

AC Arabidetalia caeruleae

Veronica alpina

Taraxacum sect. Alpina

Potentilla brauneana

Saxifraga androsacea

Carex parviflora

Alchemilla fissa

Galium noricum

Ranunculus traunfellneri

Rumex nivalis

Salix reticulata

Arabis caerulea

Doronicum glaciale

Gnaphalium hoppeanum

Trifolium pallescens

TR Thlaspion rotundifolii, Thlaspietea rotundifolii

Achillea atrata

Rhodiola rosea

Hutchinsia alpina subsp. brevicaulis

Saxifraga sedoides

Festuca nitida

Moehringia ciliata

Sedum atratum

LV Loiseleurio-Vaccinietea

Vaccinium gaultherioides

NS Nardion strictae

Nardus stricto

Coeloglossum viride

Alchemilla flabellata

JT Juncetea trifidi

Potentilla aurea

Leontodon helveticus

Campanula scheuchzeri

Geum montanum

E1

$\mathrm{E} 1+22+12+11++2 \mathrm{r}+22$

$\mathrm { E } 1 . 1 1 + 1 + 1 1 1 2 1 2 + 2 1 \longdiv { 4 }$

$\mathrm{E} 1+\mathrm{r} .+++++.+1+1$

E1

E0

E0

E0

E0

E0

E0

E0

E1

E1

E1

E1

E1

E1

E1

E

E

E

E

E

E

E1

E1

E1

E1

E1

E1

E1

E1

E1

E1

E1

E1

E1

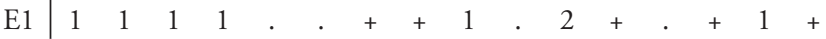

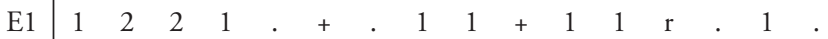

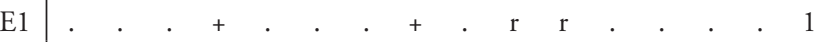

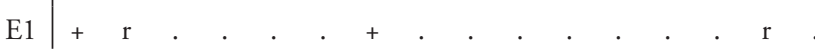




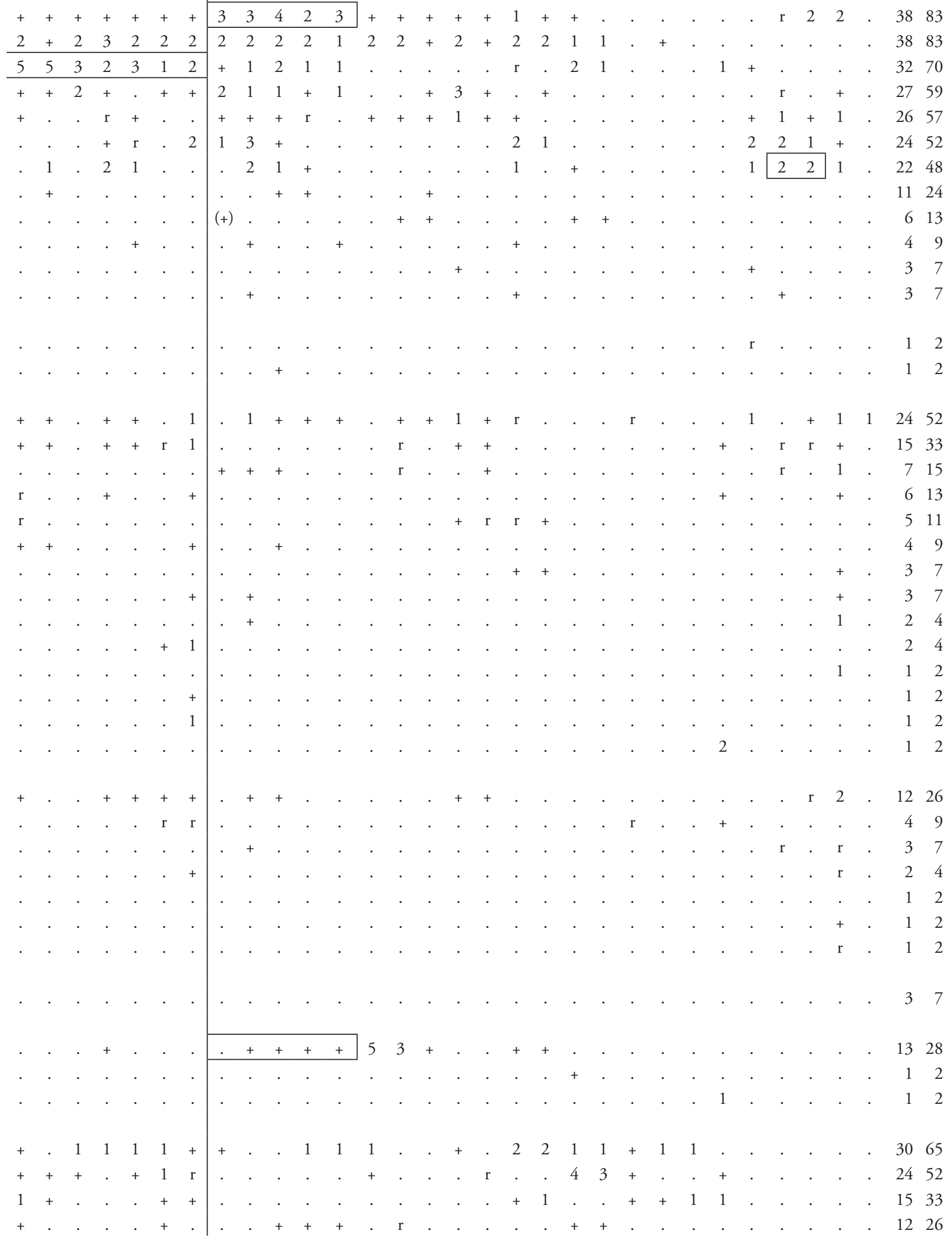


Number of relevé (Zaporedna številka popisa)

Euphrasia pulchella

Anthoxanthum nipponicum

Euphrasia minima

Hieracium alpinum

Helictotrichon versicolor

Juncus trifidus

OE Oxytropido-Elynion

Salix serpyllifolia

Antennaria carpatica

Carex atrata

Elyna myosuroides

Lloydia serotina

CF Caricion ferrugineae

Gentiana pumila

Cerastium subtriflorum

Cfir Caricion firmae

Silene acaulis

Minuartia sedoides

Veronica aphylla

Carex firma

Festuca quadriflora

Saussurea pygmaea

SV Seslerietalia coeruleae

Potentilla crantzii

Astragalus australis

Gentiana orbicularis

ES Elyno-Seslerietea

Polygonum viviparum

Euphrasia salisburgensis

Alchemilla illyrica (A. colorata)

Alchemilla exigua

Bartsia alpina

Selaginella selaginoides

Agrostis alpina

Gentianella anisodonta

Thymus praecox subsp. polytrichus

Carex sempervirens

Myosotis alpestris

SCF Scheuchzerio-Caricetea fuscae

Eriophorum scheuchzeri

Carex capillaris

MC Montio-Cardaminetea

Epilobium anagallidifolium

Saxifraga stellaris subsp. alpigena

Cratoneuron filicinum

Saxifraga aizoides

FB Festuco-Brometea

Carex caryophyllea

PaT Poo alpinae-Trisetetalia

Poa alpina

E1

E

E

E1

E1

E1

E1

E1

E1

E1

E1

E1

E1

E1

E1

E1

E1

E1

E1

E1

E1

E1

E1

E1

E1

E1

E1

E1

E1

E1

E1

E1

E1

E1

E1

E1

E1

E0

E

E1

E1 2

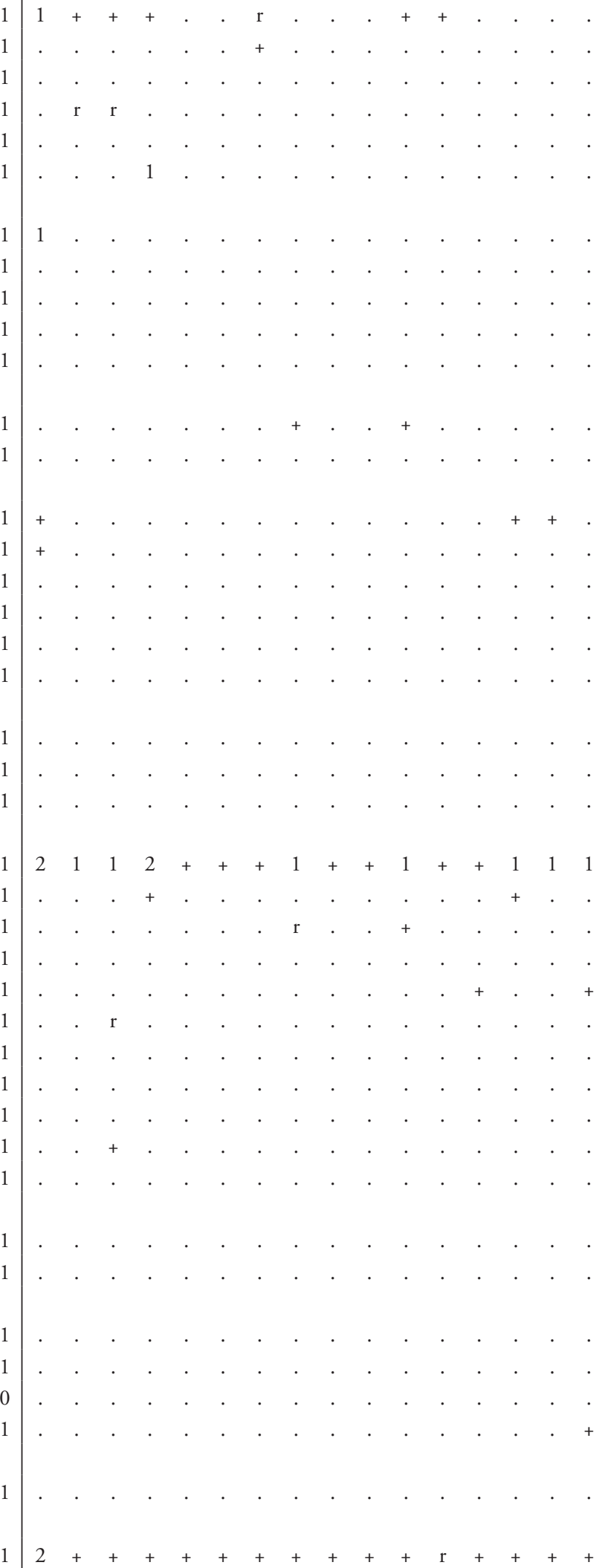



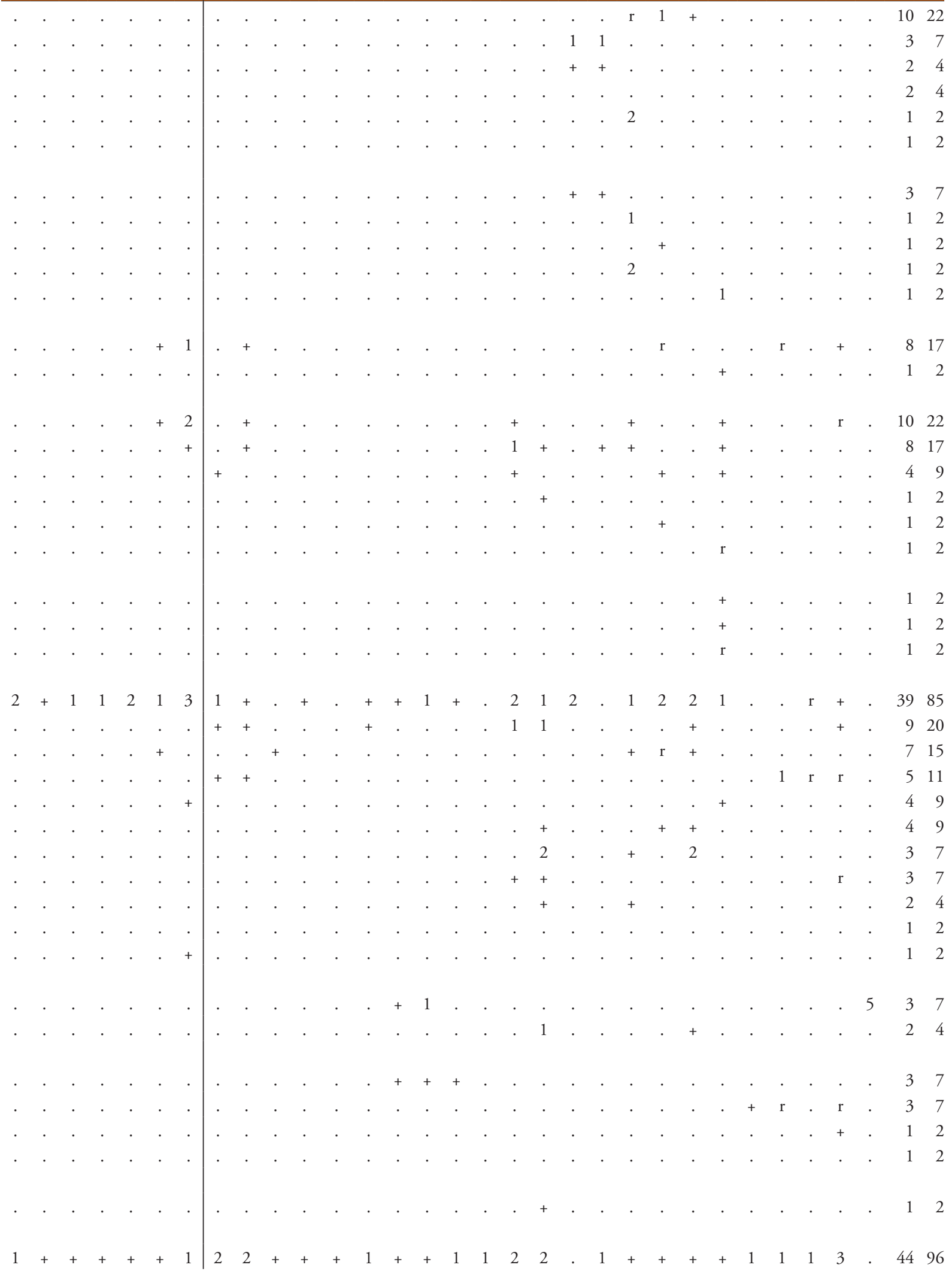
Number of relevé (Zaporedna številka popisa)

Crepis aurea

Poa supina

Phleum rhaeticum

Trollius europaeus

Deschampsia cespitosa

MuA Mulgedio-Aconitetea

Peucedanum ostruthium

Viola biflora

VP Vaccinio-Piceetea

Homogyne alpina

Hylocomium splendens

Vaccinium myrtillus

Polytrichum formosum

Pleurozium schreberi

O Other species (Druge vrste)

Epilobium sp.

Leontodon sp.

ML Mosses and lichens (Mahovi in lišaji)

Polytrichum juniperinum

Sanionia uncinata

Sciuro-hypnum starkei

Barbilophozia lycopodioides

Bartramia ithyphylla

Oncophorus virens

Pohlia sp.

Dicranum elongatum

Philonotis tomentella

Cetraria islandica

Paraleucobryum enerve

Lescuraea incurvata

Sciuro-hypnum reflexum

Distichium inclinatum

Heterocladium dimorphum

Hypnum callichroum

Lescuraea plicatum (Ptychodium plicatum)

Bryoerythrophyllum recurvirostre

Calliergonella cuspidata

Climacium dendroides

Dichodontium pellucidum

Dicranum scoparium

Tortella tortuosa

Cladonia rangiferina

Polytrichastrum alpinum

Mnium spinosum

Brachythecium glareosum

Aulacomnium palustre

Myurella julacea

Cladonia sp.

Rhizocarpon geographicum

Mnium thomsonii

E1

E

E

E

E1

E1

E1

E1

E0

E1

E0

E0

E1

E1

E0

E0

E0

E0

E0

E0

E0

E0

E0

E0

E0

E0

E0

E0

E0

E0

E0

E0

E0

E0

E0

E0

E0

E0

E0

E0

E0

E0

$\begin{array}{llllllllllllllll}1 & 2 & 3 & 4 & 5 & 6 & 7 & 8 & 9 & 10 & 11 & 12 & 13 & 14 & 15 & 16\end{array}$

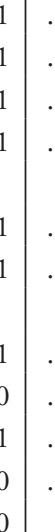

.

$1111+\mathrm{r}+.111+t_{+}+1$

$+++\mathrm{r}++\mathrm{r}+++++\mathrm{r}++$

. + . . . . . . ++ . +

+ . +++1 . + . $+1++$

+ r $r$ r . $. r .+r$ 


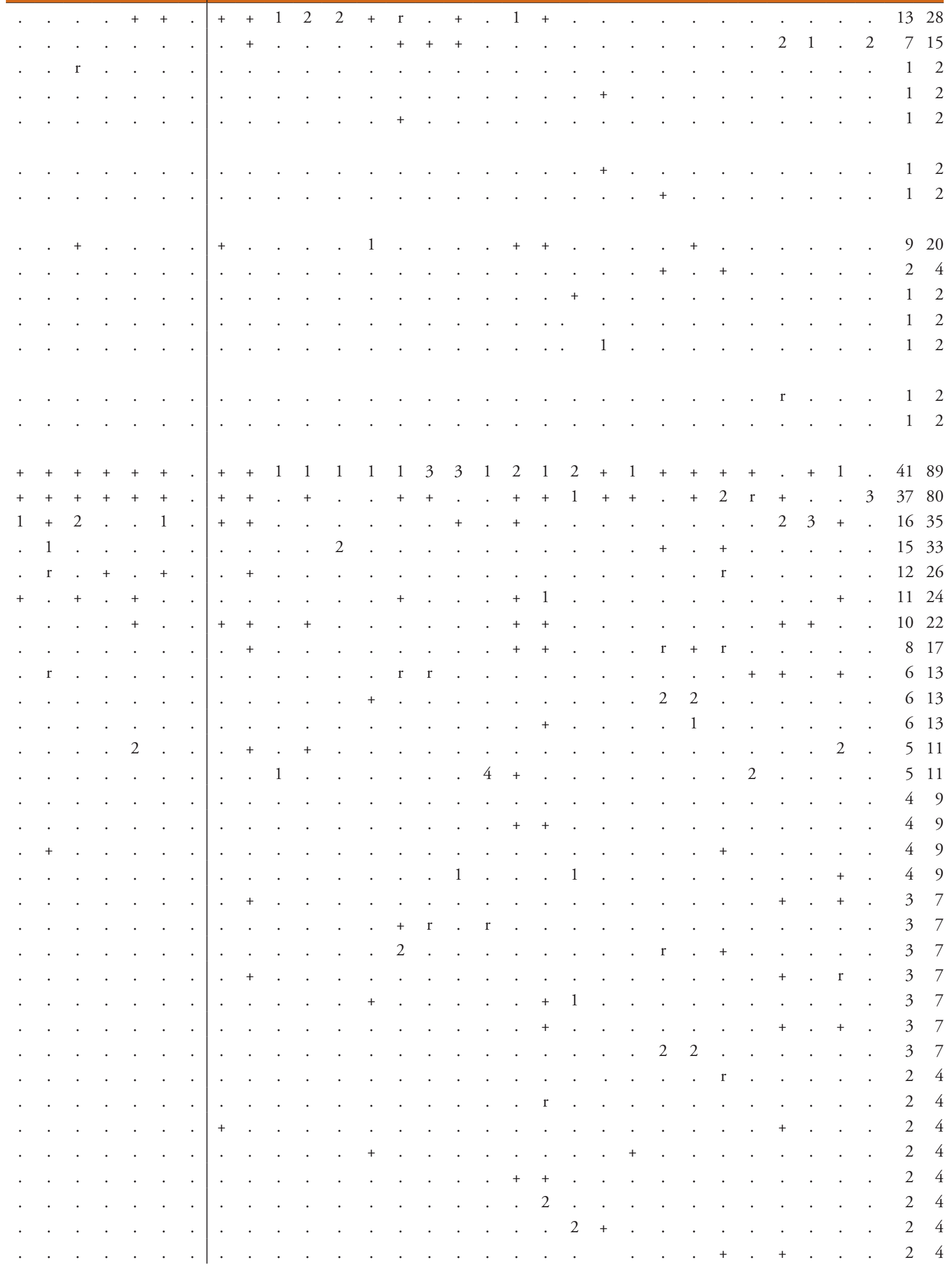




\begin{tabular}{|c|c|c|c|c|c|c|c|c|c|c|c|c|c|c|c|c|c|}
\hline Number of relevé (Zaporedna številka popisa) & & 1 & 2 & 3 & 4 & 5 & 6 & 7 & 8 & 9 & 10 & 11 & 12 & 13 & 14 & 15 & 16 \\
\hline Peltigera sp. & E0 & . & 1 & . & . & . & . & . & . & $\cdot$ & . & . & . & $\cdot$ & . & . & . \\
\hline Myurella tenerrima & E0 & . & + & - & . & . & . & $\cdot$ & . & - & . & . & . & . & . & . & . \\
\hline Dicranum undulatum & E0 & . & . & . & + & . & $\cdot$ & . & $\cdot$ & . & . & . & . & . & . & . & . \\
\hline Lescuraea radicosa & E0 & . & . & $\cdot$ & . & . & $\cdot$ & . & . & . & - & . & . & . & + & . & . \\
\hline Dicranum fuscescens & E0 & . & . & $\cdot$ & $\cdot$ & . & $\cdot$ & . & . & . & . & . & $\cdot$ & . & . & $\mathrm{r}$ & . \\
\hline Polytrichum piliferum & E0 & . & . & . & . & . & . & . & . & - & . & . & . & . & . & . & . \\
\hline Campylium stellatum & E0 & . & . & . & . & . & $\cdot$ & . & $\cdot$ & . & . & . & . & · & . & . & . \\
\hline Tortula mucronifolia & E0 & . & . & . & $\cdot$ & . & $\cdot$ & . & . & . & . & . & . & . & . & . & . \\
\hline Fissidens osmundoides & E0 & . & . & . & . & . & . & . & . & · & · & . & . & . & . & . & . \\
\hline Ptilidium ciliare & E0 & . & . & . & $\cdot$ & . & . & . & $\cdot$ & - & . & . & . & . & . & . & . \\
\hline Timmia norvegica & E0 & . & . & . & . & . & . & . & $\cdot$ & . & . & . & . & . & . & . & . \\
\hline Lescuraea saxicola & E0 & . & . & . & . & . & . & . & $\cdot$ & - & . & . & . & . & . & . & . \\
\hline Preissia quadrata & E0 & . & . & . & . & . & . & . & $\cdot$ & • & . & . & . & . & . & . & . \\
\hline Hypnum vaucheri & E0 & . & . & . & . & . & . & . & . & . & . & . & . & . & . & . & . \\
\hline Palustriella decipiens & E0 & . & . & . & . & . & . & . & . & - & . & . & . & . & . & . & . \\
\hline Plagiochila porelloides & E0 & . & $\cdot$ & • & · & . & . & . & . & • & . & . & . & · & . & . & . \\
\hline Syntrichia ruralis & E0 & . & . & . & . & . & . & . & . & . & $\cdot$ & . & . & . & . & . & . \\
\hline Ditrichum flexicaule & E0 & . & $\cdot$ & . & $\cdot$ & . & . & $\cdot$ & . & & . & . & . & . & . & . & . \\
\hline Distichium capillaceum & E0 & . & . & . & . & . & . & . & · & & . & . & . & . & . & . & . \\
\hline Syntrichia norvegica & E0 & . & . & $\cdot$ & . & . & $\cdot$ & . & $\cdot$ & . & . & . & . & . & . & . & . \\
\hline
\end{tabular}

\section{Legend - Legenda}

Acronym of syntaxa - see Text - okrajšave sintaksonov so pojasnjene v besedilu

TW - Tone Wraber

AM - Andrej Martinčič

ID - Igor Dakskobler

A Limestone - apnenec

L Marlstone - laporovec

R Chert - roženec

Gr Gravel - grušč

Re Rendzina - rendzina

Gr Gravel - grušč

Gl Molic Gleysols - organsko-mineralna tla

Pr. Presence (number of relevés in which the species is presented) - število popisov, v katerih se pojavlja vrsta

Fr. Frequency in \% - frekvenca v \%

Sciuro-hypnum glaciale* This moss species was collected by Tone Wraber (14. 9. 1967) in the stand of the association Salicetum herbaceae s. lat. also on the locality Na Jezerih-Rokavi. Andrej Martinčič found it in Srečko Grom's collection and determined it in 2018.

Sciuro-hypnum glaciale* To mahovno vrsto je nabral Tone Wraber (14. 9. 1967) v združbi zelnate vrbe tudi na nahajališču Na jezerih-Rokavi. Andrej Martinčič jo je našel v zbirki Srečka Groma in jo določil leta 2018. 


\begin{tabular}{|c|c|c|c|c|c|c|c|c|c|c|c|c|c|c|c|c|c|c|c|c|c|c|c|c|c|c|c|c|c|c|}
\hline & 18 & 19 & & & 2 & & & & & & & & & & & & & & & & & & & & & & & & & \\
\hline & . & . & & . & . & & . & . & . & . & . & . & . & . & & . & $\cdot$ & & . & . & 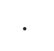 & . & 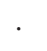 & . & . & . & & 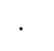 & 1 & \\
\hline & . & 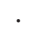 & & . & & & . & . & . & 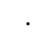 & 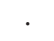 & . & & 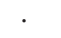 & & & . & & . & 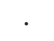 & . & 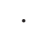 & & . & 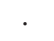 & & & & & \\
\hline & . & 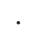 & & . & 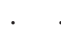 & & & 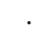 & . & 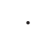 & . & 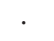 & & & & & 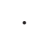 & & & & . & & & & & & & & 1 & \\
\hline & . & . & & . & 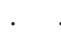 & & & . & . & . & . & . & & & & & 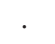 & & & & 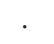 & & & & & & & & 1 & \\
\hline & . & . & & . & 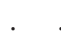 & & 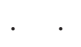 & $\cdot$ & . & . & . & & & . & & 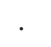 & & . & . & 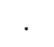 & . & . & . & . & . & & & & 1 & \\
\hline & & 1 & & . & 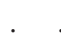 & & 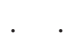 & 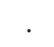 & . & . & . & . & . & 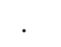 & & . & . & . & . & 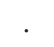 & . & . & 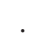 & 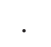 & . & & & & & \\
\hline & . & . & & . & . & & + & . & . & . & . & . & . & . & & 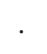 & . & . & . & 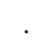 & . & . & . & . & 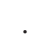 & & & . & 1 & \\
\hline & . & . & & . & . & & . & . & . & . & . & . & . & . & & + & . & . & . & . & 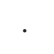 & . & $\cdot$ & 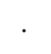 & & & & & 1 & \\
\hline & . & . & & . & . & & . & . & . & . & . & & . & . & & . & + & . & . & . & . & . & . & . & & & & & 1 & \\
\hline & . & . & & & . & & $\cdot$ & . & . & . & . & . & . & 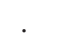 & & $\cdot$ & . & ${ }^{\circ}$ & . & . & + & . & . & . & & & & & & \\
\hline & . & . & & . &. & & . & . & . & . & . & . & & . & & . & . & . & & 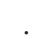 & 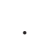 & . & 2 & 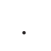 & . & & & . & 1 & \\
\hline & . & . & & . & & & . & . & . & . & . & . & & . & & & . & & . & & 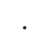 & 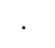 & + & 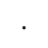 & & & & & 1 & \\
\hline & . & . & & & . & & . & . & . & . & . & . & & . & & & . & & . & . & & . & . & 2 & . & & & & 1 & \\
\hline . & . & . & & &. & & $\cdot$ & 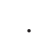 & . & 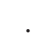 & . & . & & . & & . & . & $\cdot$ & . & 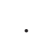 & . & . & . & . & + & & & . & 1 & \\
\hline . & . & . & & . &. & & . & ${ }^{\circ}$ & . & . & . & & . & . & & . & & . & . & 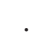 & . & . & . & . & + & & & . & 1 & \\
\hline & . & . & & & . & & . & . & . & 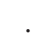 & 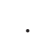 & . & & . & & 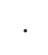 & 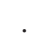 & & & . & & & . & 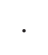 & + & & & . & 1 & \\
\hline & . & . & & . & . & & 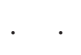 & . & . & . & . & & & $\cdot$ & & & . & & . & · & . & & . & . & ${ }^{t}$ & & & . & 1 & \\
\hline & . & . & & . & & & . & . & . & . & . & & & . & & & 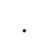 & & . & & . & & & $\cdot$ & + & & & & 1 & \\
\hline & . & 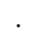 & & & & & . & $\cdot$ & . & . & r. & . & & . & & & . & & 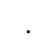 & . & & 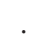 & & $\cdot$ & ${ }^{\circ}$ & & 1 & . & 1 & \\
\hline & & & & & & & & & & & & & & & & & & & & & & & & & & & & & & \\
\hline
\end{tabular}


Table 2: Synoptic table of the association Salicetum herbaceae s. lat. in the Central, Eastern, Southern and Southeastern Alps Tabela 2: Sintezna preglednica asociacije Salicetum herbaceae s. lat. v Centralnih, Vzhodnih, Južnih in Jugovzhodnih Alpah

\begin{tabular}{|c|c|c|c|c|c|c|c|}
\hline Successive number (Zaporedna številka) & & 1 & 2 & 3 & 4 & 5 & 6 \\
\hline Number of relevés (Število popisov) & & 23 & 10 & 12 & 3 & 7 & 31 \\
\hline Sign for syntaxa (Oznaka sintaksonov) & & SrSh & Sh-Do & Sh-BB & Sh-Eg & ShAc-Eg & ShAc-Eng \\
\hline Author of of relevés (Avtor popisov) & & TWAM & ESP & $\mathrm{BB}$ & PEg & PEg & TE \\
\hline \multicolumn{8}{|l|}{ Salicion herbaceae, Salicetea herbaceae } \\
\hline Salix herbacea & E1 & 91 & 100 & 92 & 100 & 100 & 100 \\
\hline Gnaphalium supinum & E1 & 96 & 30 & 100 & . & 14 & 29 \\
\hline Soldanella pusilla & E1 & 100 & 10 & 50 & 67 & 43 & 71 \\
\hline Luzula alpinopilosa & E1 & 96 & 20 & 33 & . & . & 52 \\
\hline Sibbaldia procumbens & E1 & 70 & 30 & 83 & . & . & 6 \\
\hline Sagina saginoides & E1 & 52 & 50 & 58 & 67 & 71 & 61 \\
\hline Anthelia juratzkana & E0 & 65 & . & 8 & 33 & 57 & 16 \\
\hline Polytrichastrum sexangulare & E0 & 57 & 60 & 25 & . & . & 3 \\
\hline Kiaeria falcata & E0 & 74 & . & 17 & . & . & . \\
\hline Poblia obtusifolia & E0 & 52 & . & 8 & . & . & 6 \\
\hline Scapania helvetica & E0 & 35 & . & . & . & . & . \\
\hline Pohlia drummondii & E0 & 4 & . & 67 & . & . & . \\
\hline Sciuro-hypnum glaciale & E0 & 4 & . & 25 & . & . & . \\
\hline Kiaeria starkei & E0 & 4 & . & . & . & . & . \\
\hline Cerastium cerastioides & E1 & . & 20 & 75 & 33 & 14 & 16 \\
\hline Cardamine alpina & E1 & . & . & 67 & . & . & 3 \\
\hline Arenaria biflora & E1 & . & . & 50 & . & . & . \\
\hline Alchemilla pentaphyllea & E1 & . & . & 17 & . & . & 3 \\
\hline Carex lachenalii & E1 & . & . & 25 & . & . & . \\
\hline Carex foetida & E1 & . & . & 8 & . & . & 3 \\
\hline Plantago atrata & E1 & . & . & . & 67 & 57 & 13 \\
\hline Alchemilla decumbens & E1 & . & . & . & 67 & . & 6 \\
\hline \multicolumn{8}{|l|}{ Androsacetalia alpinae } \\
\hline Veronica alpina & E1 & 43 & 60 & 67 & 67 & 71 & 29 \\
\hline Gentiana bavarica & E1 & . & 10 & . & 67 & 57 & 58 \\
\hline Sedum alpestre & E1 & . & . & 42 & . & . & . \\
\hline Epilobium anagallidifolium & E1 & . & . & 17 & . & 14 & 3 \\
\hline \multicolumn{8}{|l|}{ Arabidetalia caeruleae } \\
\hline Salix retusa & E1 & 96 & 70 & . & . & 43 & 48 \\
\hline Taraxacum sect. Alpina & E1 & 35 & 30 & 92 & . & 71 & 55 \\
\hline Saxifraga androsacea & E1 & 17 & 50 & 8 & 67 & 86 & 71 \\
\hline Alchemilla fissa & E1 & 13 & . & . & . & . & 10 \\
\hline Salix reticulata & E1 & 9 & 40 & . & . & . & 3 \\
\hline Pseudoleskea incurvata (= Lescuraea incurvata) & E0 & 9 & . & . & . & 43 & 16 \\
\hline Carex parviflora & E1 & 4 & 80 & . & 67 & 100 & 71 \\
\hline Gnaphalium hoppeanum & E1 & 4 & 20 & . & . & 57 & 23 \\
\hline Ranunculus traunfellneri & E1 & 4 & . & . & . & . & . \\
\hline Doronicum glaciale & E1 & 4 & . & . & . & . & . \\
\hline Potentilla brauneana & E1 & . & 40 & . & 67 & 29 & 23 \\
\hline Soldanella minima & E1 & . & 40 & . & . & . & 3 \\
\hline Taraxacum kalbusssii & E1 & . & 40 & . & . & . & . \\
\hline Alchemilla glaberima & E1 & . & 40 & 8 & . & . & . \\
\hline Arabis caerulea & E1 & . & 30 & . & . & . & 23 \\
\hline
\end{tabular}




\begin{tabular}{|c|c|c|c|c|c|c|c|}
\hline Successive number (Zaporedna številka) & & 1 & 2 & 3 & 4 & 5 & 6 \\
\hline Achillea oxyloba & E1 & . & 30 & . & . & . & 6 \\
\hline Soldanella alpina & E1 & . & 20 & . & . & 14 & 29 \\
\hline Trifolium pallescens & E1 & . & 10 & . & . & . & . \\
\hline Ranunculus alpestris & E1 & . & . & . & 33 & 100 & 87 \\
\hline Arabis bellidifolia & E1 & . & . & . & . & 14 & 16 \\
\hline Rumex nivalis & E1 & . & . & . & . & . & 13 \\
\hline Campanula pulla & E1 & . & . & . & . & . & 6 \\
\hline Soldanella austriaca & E1 & . & . & . & . & . & 3 \\
\hline \multicolumn{8}{|c|}{ Thlaspion rotundifolii, Thlaspietea rotundifolii } \\
\hline Achillea atrata & E1 & 26 & . & . & 100 & 100 & 68 \\
\hline Rhodiola rosea & E1 & 9 & . & . & . & . & . \\
\hline Saxifraga sedoides & E1 & 4 & 20 & . & . & . & . \\
\hline Festuca nitida & E1 & 4 & . & . & . & . & . \\
\hline Armeria alpina & E1 & . & 50 & . & . & . & . \\
\hline Hutchinsia alpina subsp. brevicaulis & E1 & . & 20 & . & . & 71 & 55 \\
\hline Saxifraga oppositifolia & E1 & . & . & 8 & . & . & . \\
\hline Festuca rupicaprina & E1 & . & . & . & 33 & 57 & 29 \\
\hline Cirsium spinosissimum & E1 & . & . & . & 33 & 14 & 16 \\
\hline Poa minor & E1 & . & . & . & . & 41 & 10 \\
\hline Campanula cochleariifolia & E1 & . & . & . & . & 14 & 3 \\
\hline Silene vulgaris glareosa & E1 & . & . & . & . & 14 & . \\
\hline Moehringia ciliata & E1 & . & . & . & . & 86 & 42 \\
\hline Sedum atratum & E1 & . & . & . & . & 29 & 16 \\
\hline Achillea clusiana & E1 & . & . & . & . & . & 3 \\
\hline Cerastium carinthiacum & E1 & . & . & . & . & . & 3 \\
\hline \multicolumn{8}{|l|}{ Asplenietea trichomanis } \\
\hline Draba aizoides & E1 & . & . & . & . & . & 3 \\
\hline Silene pusilla & E1 & . & . & . & . & . & 3 \\
\hline Primula clusiana & E1 & . & . & . & . & . & 3 \\
\hline \multicolumn{8}{|l|}{ Loiseleurio-Vaccinietea } \\
\hline Vaccinium gaultherioides & E1 & 13 & 10 & . & . & . & . \\
\hline Loiseleuria procumbens & E1 & . & 20 & . & . & . & . \\
\hline \multicolumn{8}{|l|}{ Nardion strictae } \\
\hline Nardus stricta & E1 & 17 & . & $\cdot$ & . & . & 3 \\
\hline Festuca cf. ovina & E1 & . & 10 & . & . & . & . \\
\hline Plantago alpina & E1 & . & . & 8 & . & 29 & 13 \\
\hline \multicolumn{8}{|l|}{ Juncetea trifidi } \\
\hline Agrostis rupestris & E1 & 100 & 20 & 17 & 33 & . & 3 \\
\hline Potentilla aurea & E1 & 78 & 10 & 33 & . & . & 3 \\
\hline Leontodon helveticus & E1 & 78 & 10 & 8 & . & . & . \\
\hline Juncus jacquinii & E1 & 78 & . & . & . & . & . \\
\hline Campanula scheuchzeri & E1 & 39 & 30 & . & 67 & 100 & 58 \\
\hline Geum montanum & E1 & 26 & . & . & . & . & . \\
\hline Euphrasia pulchella & E1 & 30 & . & . & . & . & . \\
\hline Hieracium alpinum & E1 & 9 & . & . & . & . & . \\
\hline Anthoxanthum nipponicum & E1 & 4 & 10 & . & . & . & 3 \\
\hline Juncus trifidus & E1 & 4 & . & . & . & . & . \\
\hline
\end{tabular}




\begin{tabular}{|c|c|c|c|c|c|c|c|}
\hline Successive number (Zaporedna številka) & & 1 & 2 & 3 & 4 & 5 & 6 \\
\hline Carex curvula & E1 & . & 30 & 42 & . & . & 3 \\
\hline Phyteuma hemisphaericum & E1 & . & 10 & . & . & . & \\
\hline Primula minima & E1 & . & 20 & . & . & . & 3 \\
\hline Leucanthemopsis alpina & E1 & . & 10 & 50 & . & . & 45 \\
\hline Senecio incanus subsp. carniolicus & E1 & . & 10 & . & . & . & . \\
\hline Veronica bellidioides & E1 & . & 10 & . & . & . & . \\
\hline Euphrasia minima & E1 & . & . & 17 & . & 14 & 26 \\
\hline Luzula spicata & E1 & . & . & . & 33 & . & 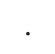 \\
\hline Ligusticum mutellinoides & E1 & . & . & . & . & . & 10 \\
\hline Androsace obtusifolia & E1 & . & . & . & . & . & 6 \\
\hline \multicolumn{8}{|l|}{ Oxytropido-Elynion } \\
\hline Salix serpyllifolia & E1 & 4 & 10 & . & . & . & . \\
\hline Antennaria carpatica & E1 & . & 10 & . & . & . & . \\
\hline Elyna myosuroides & E1 & . & 10 & . & . & . & 3 \\
\hline Gentiana nivalis & E1 & . & 10 & . & . & . & . \\
\hline Carex atrata & E1 & . & . & . & . & . & 16 \\
\hline \multicolumn{8}{|l|}{ Caricion ferrugineae } \\
\hline Gentiana pumila & E1 & 17 & . & . & . & . & . \\
\hline Trifolium thalii & E1 & . & 20 & . & . & . & . \\
\hline Festuca nigricans (F melanopsis) & E1 & . & . & . & . & . & 6 \\
\hline \multicolumn{8}{|l|}{ Caricion firmae } \\
\hline Silene acaulis & E1 & 22 & 60 & . & 33 & 29 & 32 \\
\hline Minuartia sedoides & E1 & 9 & . & 17 & . & 14 & 3 \\
\hline Carex firma & E1 & . & 10 & . & . & . & 3 \\
\hline Veronica aphylla & E1 & . & . & . & 33 & 14 & 6 \\
\hline Festuca quadriflora & E1 & . & . & . & . & 14 & 13 \\
\hline Saussurea pygmaea & E1 & . & . & . & . & . & . \\
\hline Carex ornithopodioides & E1 & . & . & . & . & . & 10 \\
\hline \multicolumn{8}{|l|}{ Seslerietalia coeruleae } \\
\hline Gentiana orbicularis & E1 & . & 10 & . & . & . & . \\
\hline Ranunculus carinthiacus & E1 & . & 10 & . & . & . & . \\
\hline Galium anisophyllon & E1 & . & . & . & 33 & 14 & 3 \\
\hline \multicolumn{8}{|l|}{ Elyno-Seslerietea } \\
\hline Polygonum viviparum & E1 & 100 & 80 & 33 & 67 & 86 & 74 \\
\hline Homogyne discolor & E1 & 48 & . & . & . & . & . \\
\hline Bartsia alpina & E1 & 13 & 10 & . & . & . & 26 \\
\hline Alchemilla illyrica (A. colorata) & E1 & 13 & . & . & . & . & . \\
\hline Euphrasia salisburgensis & E1 & 9 & . & . & . & . & 3 \\
\hline Selaginella selaginoides & E1 & 4 & 10 & . & . & 43 & 6 \\
\hline Myosotis alpestris & E1 & 4 & . & . & . & . & 29 \\
\hline Carex sempervirens & E1 & 4 & . & . & . & . & . \\
\hline Lotus alpinus & E1 & . & 10 & . & . & . & . \\
\hline Gentiana verna & E1 & . & 10 & . & . & . & . \\
\hline Ligusticum mutellina & E1 & . & 10 & 50 & 67 & 57 & 3 \\
\hline Ranunculus montanus & E1 & . & . & 8 & 33 & 29 & 26 \\
\hline Carex ornithopoda & E1 & . & . & . & . & 14 & . \\
\hline Sesleria caerulea & E1 & . & . & . & . & 29 & 6 \\
\hline Viola calcarata & E1 & . & . & . & . & . & 10 \\
\hline Aster bellidiastrum & E1 & . & . & . & . & . & 6 \\
\hline Saxifraga exarata subsp. moschata & E1 & . & . & . & . & . & 6 \\
\hline
\end{tabular}




\section{Successive number (Zaporedna številka)}

Leucanthemum atratum

Scheuchzerio-Caricetea fuscae

Juncus triglumis

Carex capillaris

Carex fusca

Phleum alpinum

Carex nigra

\section{Montio-Cardaminetea}

Saxifraga aizoides

Saxifraga stellaris s. lat.

Montia rivularis

Philonotis fontana

Epilobium alsinifolium

Cratoneuron filicinum

Palustriella commutata

Poo alpinae-Trisetetalia

Poa alpina

Crepis aurea

Phleum rhaeticum

Poa supina

Trollius europaeus

Deschampsia cespitosa

Poa annua var. varia

Sagina glabra

Trifolium pratense subsp. nivale

Leontodon hispidus

Mulgedio-Aconitetea

Salix waldsteiniana

Gagea fragifera

Vaccinio-Piceetea

Homogyne alpina

Polytrichum formosum

Other species (Druge vrste)

Leontodon sp.

Taraxacum sp.

Mosses and lichens (Mahovi in lišaji)

Polytrichum juniperinum

Sanionia uncinata

Barbilophozia lycopodioides

Bartramia ithyphylla

Sciuro-hypnum starkei

Oncophorus virens

Paraleucobryum enerve

Distichium inclinatum

Pohlia sp.

Cetraria islandica

Hypnum callichroum

Dicranum elongatum

Heterocladium dimorphum

Polytrichastrum alpinum

\section{2}

3

4

E1

E1

E1

E1

E1

17

17

E1

E1

E1

E1

E1

E0

E1

E1

E1

E1

E1

E1

E1

E1

E1

E1

E1

E1

E1

E1

E1

10

E1

E0

17

10

40

10

.

.

.

14

14

60

83

33

71

87

40

33

6

14

13

20

10

10

29

13

33

8

10

6

E1

E1

4

E1

E0

E0

87

60

33

14

E0

E0

E0

E0

E0

E0

E0

E0

E0

E0

E0

E0 


\begin{tabular}{|c|c|c|c|c|c|c|c|}
\hline Successive number (Zaporedna številka) & & 1 & 2 & 3 & 4 & 5 & 6 \\
\hline Cladonia rangiferina & E0 & 4 & 10 & . & 33 & 29 & 3 \\
\hline Cladonia sp. (pyxidata) & E0 & 4 & 10 & 33 & . & . & 3 \\
\hline Polytrichum piliferum & E0 & 4 & . & 25 & . & . & . \\
\hline Sciuro-hypnum reflexum & E0 & 2 & . & 8 & . & . & . \\
\hline Lescuraea plicatum (Ptychodium plicatum) & E0 & 4 & . & . & . & . & 6 \\
\hline Philonotis tomentella & E0 & 4 & . & . & . & . & . \\
\hline Mnium spinosum & E0 & 4 & . & . & . & . & . \\
\hline Dicranum fuscescens & E0 & 4 & . & . & . & . & . \\
\hline Dicranum undulatum & E0 & 4 & . & . & . & . & . \\
\hline Lescuraea radicosa & E0 & 4 & . & . & . & . & . \\
\hline Myurella tenerrima & E0 & 4 & . & . & . & . & . \\
\hline Peltigera sp. & E0 & 4 & . & . & . & . & . \\
\hline Cetraria aculeata & E0 & . & 10 & . & . & . & . \\
\hline Rhacomitrum canescens & E0 & . & 10 & . & . & & . \\
\hline Desmatodon latifolius & E0 & . & . & 17 & . & . & . \\
\hline Peltigera rufescens & E0 & . & . & 17 & . & . & . \\
\hline Aulacomnium palustre & E0 & . & . & 8 & . & . & . \\
\hline Pohlia filum & E0 & . & . & 8 & . & . & . \\
\hline Pleuroclada albescens & E0 & . & . & 8 & . & . & . \\
\hline Bryum elegans & E0 & . & . & 8 & . & . & . \\
\hline Lophozia alpestris & E0 & . & . & 8 & . & . & . \\
\hline Lecidea neglecta & E0 & . & . & 8 & . & . & . \\
\hline Brachythecium glareosum & E0 & . & . & . & 33 & 29 & . \\
\hline Tortella tortuosa & E0 & . & . & . & 33 & 14 & 19 \\
\hline Bryum sp. & E0 & . & . & . & 33 & 57 & 3 \\
\hline Distichium capillaceum & E0 & . & . & . & . & 71 & 32 \\
\hline Dichodontium pellucidum & E0 & . & . & . & . & 14 & . \\
\hline Ditrichum flexicaule & E0 & . & . & . & . & 14 & . \\
\hline Pohlia cruda & E0 & . & . & . & . & 14 & 3 \\
\hline Bryum pseudotriquetrum & E0 & . & . & . & . & . & 6 \\
\hline Preissia quadrata & E0 & . & . & . & . & . & 3 \\
\hline Syntrichia norvegica & E0 & . & . & . & . & . & 3 \\
\hline Scapania aequiloba & E0 & . & . & . & . & . & 3 \\
\hline Cladonia arbuscula & E0 & & . & & 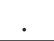 & . & 3 \\
\hline
\end{tabular}

\section{Legend - Legenda}

1 Salicetum retuso-herbaceae, Julian Alps, this article

2 Salicetum herbaceae, Dolomites, E. \& S. Pignatti 2014, 2016

3 Salicetum herbaceae, Central Alps, Braun-Blanquet 1926

4 Salicetum herbaceae, Eastern Alps, Eggensberger 1994

5 Arabidetum caeruleae salicetosum herbaceae, Eastern Alps, Eggensberger 1994

6 Salici herbaceae-Arabidetum caeruleae var. Pritzelago alpina-Salix retusa, Eastern Alps, Englisch 1999 
Table 3: Groups of diagnostic species in the communities with dominant Salix herbacea in the Alps (relative frequencies).

Tabela 3: Skupine diagnostičnih vrst v združbah s prevladujočo vrtso Salix herbacea v Alpah (relativne frekvence).

\begin{tabular}{|c|c|c|c|c|c|c|}
\hline Successive number (Zaporedna številka) & 1 & 2 & 3 & 4 & 5 & 6 \\
\hline Number of relevés (Število popisov) & 23 & 10 & 12 & 3 & 7 & 31 \\
\hline Sign for syntaxa (Oznaka sintaksonov) & SrSh & Sh-Do & Sh-BB & Sh-Eg & ShAc-Eg & ShAc-Eng \\
\hline Author of of relevés (Avtor popisov) & TWAM & ESP & $\mathrm{BB}$ & PEg & PEg & $\mathrm{TE}$ \\
\hline Salicion herbaceae, Salicetea herbaceae & 32,7 & 16,8 & 47,0 & 23,3 & 14,5 & 19,2 \\
\hline Androsacetalia alpinae & 1,8 & 3,7 & 7,1 & 7,2 & 5,8 & 4,5 \\
\hline Arabidetalia caeruleae & 7,6 & 28,4 & 6,1 & 12,6 & 22,7 & 25 \\
\hline Thlaspion rotundifolii, Thlaspietea rotundifolii & 1,8 & 4,7 & 0,5 & 8,9 & 17,4 & 12,1 \\
\hline Asplenietea trichomanis & 0 & 0 & 0 & 0 & 0 & 0,4 \\
\hline Loiseleurio-Vaccinietea & 0,5 & 1,6 & 0 & 0 & 0 & 0 \\
\hline Nardion strictae & 0,7 & 0,5 & 0,5 & 0 & 1,2 & 0,8 \\
\hline Juncetea trifidi & 18,3 & 8,9 & 9,4 & 7,1 & 4,7 & 7,9 \\
\hline Oxytropido-Elynion & 0,2 & 2,1 & 0 & 0 & 0 & 0,9 \\
\hline Caricion ferrugineae & 0,7 & 1,1 & 0 & 0 & 0 & 0,3 \\
\hline Caricion firmae & 1,2 & 3,7 & 0,1 & 3,5 & 2,9 & 3,3 \\
\hline Seslerietalia coeruleae & 0 & 1,1 & 0 & 1,8 & 0,6 & 0,1 \\
\hline Elyno-Seslerietea & 8,0 & 6,8 & 5,1 & 9,0 & 10,5 & 9,8 \\
\hline Scheuchzerio-Caricetea fuscae & 0 & 2,1 & 1,9 & 0 & 0 & 0,3 \\
\hline Montio-Cardaminetea & 0,2 & 2,6 & 0,9 & 3,5 & 3,5 & 2,4 \\
\hline Poo alpinae-Trisetetalia & 4,8 & 7,4 & 7,0 & 3,5 & 4,7 & 6,7 \\
\hline Mulgedio-Aconitetea & 0 & 0,5 & 0,1 & 0 & 0 & 0 \\
\hline Vaccinio-Piceetea & 0,7 & 0,5 & 0,5 & 3,5 & 0 & 0,6 \\
\hline Other species (Druge vrste) & 0,2 & 0 & 0 & 1,8 & 0,6 & 0 \\
\hline Mosses and lichens (Mahovi in lišaji) & 20,6 & 7,4 & 12,1 & 14,2 & 11 & 5,6 \\
\hline Total (Skupaj) & 100,0 & 100 & 100 & 100 & 100 & 100 \\
\hline
\end{tabular}

\section{Legend - Legenda}

1 Salicetum retuso-herbaceae, Julian Alps, this article

2 Salicetum herbaceae, Dolomites, E. \& S. Pignatti 2014, 2016

3 Salicetum herbaceae, Central Alps, Braun-Blanquet 1926

4 Salicetum herbaceae, Eastern Alps, Eggensberger 1994

5 Arabidetum caeruleae salicetosum herbaceae, Eastern Alps, Eggensberger 1994

6 Salici herbaceae-Arabidetum caeruleae var. Pritzelago alpina-Salix retusa, Eastern Alps, Englisch 1999 